\title{
ARTICLES \\ The BRANDENBURG PARAdigm AND OTHER FIRST AMENDMENTS
}

\begin{abstract}
Steven G. Gey
This Article addresses the fracturing of modern First Amendment law into multiple, different sets of rules and rationales for the protection of speech, depending on what kind of speech is at issue. It is no longer accurate to say that there is one universal First Amendment jurisprudence; indeed, it is no longer accurate to say that there is one First Amendment. Today there are many different-often very different_First Amendments for different types of speech. On a practical level, this fracturing of First Amendment law creates difficulties only in that it requires litigators and judges addressing First Amendment issues to identify the category or categories into which a particular example of speech fits. But on a theoretical level, the fracturing of First Amendment jurisprudence is much more problematic. These theoretical problems arise because First Amendment jurisprudence is not just a collection of narrow rules and doctrines. These rules and doctrines are based on series of presuppositions about the nature of individuals, the proper relationship between the government and its citizens, the extent to which society should accept risks posed by dangerous or antisocial ideas, and the liability of speakers for the consequences of their speech. The problem is that the courts make one set of assumptions when dealing with one area of expression and very different (and often contradictory) assumptions when dealing with other areas of expression.
\end{abstract}

This Article starts by describing the baseline for all free speech jurisprudence-the jurisprudence that applies to political advocacy. It then distills from the Court's major political speech cases a set of principles that I call "the Brandenburg paradigm." The remainder of the Article discusses whether the theoretical assumptions made in the Brandenburg paradigm also should be applied to areas of speech other than political advocacy. I address several areas of expression specifically, including threats, obscenity, "teaching speech," and student speech in public schools. An assessment of these different speech categories indicates that there is no good reason to ignore the Brandenburg paradigm outside the political advocacy category. Indeed, a very good reason exists to apply the Brandenburg paradigm to the entire range of First Amendment issues: the assumptions that underlie Brandenburg-for example, that citizens control the government rather than vice versa, that citizens should develop their own value systems free of government coercion, and that the government should suppress ideas it dislikes only in the face of serious, concrete harms stemming from that expression-should not be regarded solely as artifacts of the First Amendment but rather as indispensable elements of constitutional democracy itself.

Modern First Amendment jurisprudence increasingly resembles a game of three-dimensional chess. One dimension contains the special procedural rules that attach to First Amendment cases, such as the prior restraint doctrine or the requirement that certain regulations be submitted to judicial oversight before they are enforced

* David and Deborah Fonvielle and Donald and Janet Hinkle Professor of Law, Florida State University. 
against individual speakers. A second dimension includes the special interpretive rules that apply in First Amendment cases, such as the overbreadth doctrine, the more rigorous treatment of due process rules against vague regulations, and the general prohibition against unfettered administrative discretion in regulating speech. The third dimension includes the many different constitutional rules that apply to diverse types of expressive content. When these various dimensions are put together, they seem to produce a system of free speech regulation governed by not one, but many different First Amendments. To know whether any particular expression is constitutionally protected, therefore, the observer first has to determine which First Amendment applies.

Of course, at one level this perception is clearly wrong; there is obviously only one First Amendment in the constitutional text, and the same forty-five words apply to every instance in which the government attempts to regulate or suppress speech or religion. On the other hand, if one focuses on the doctrine and jurisprudence that the courts have gleaned from these forty-five words, it is not implausible to suggest that in fact many different First Amendments apply to the government's regulation of individual expression. Indeed, the subject-specific First Amendments have proliferated to the point that it is becoming difficult to keep track of exactly how many there are. A non-exhaustive list of First Amendments might include the following: a political speech First Amendment, ${ }^{1}$ a "true threats" First Amendment, ${ }^{2}$ a national security First Amendment, ${ }^{3}$ a "teaching speech" First Amendment, ${ }^{4}$ a fighting words First Amendment, ${ }^{5}$ a hostile au-

1 See Brandenburg v. Ohio, 395 U.S. 444 (1969) (describing the First Amendment rules protecting political speech, which do not permit the government to punish a speaker unless the government can prove that the speaker engaged in incitement, created a clear and present danger, and intended to cause immediate harm as a result of the speech); see also NAACP v. Claiborne Hardware Co., 458 U.S. 886, 927-28 (1982) (applying Brandenburg to aggressively menacing political speech); Hess v. Indiana, 414 U.S. 105, 108 (1973) (per curiam) (applying Brandenburg and elaborating on the Brandenburg immediate harm requirement).

2 See Virginia v. Black, 538 U.S. 343, 359 (2003) (noting that the First Amendment permits "a State to ban a 'true threat"); United States v. Kelner, 534 F.2d 1020, 1026 (2d Cir. 1976), cert. denied, 429 U.S. 1022 (1976) (describing one possible standard for adjudicating First Amendment "true threats").

3 See N.Y. Times v. United States, 403 U.S. 713, $726-27$ (1971) (asserting that "only governmental allegation and proof that publication [of a national security document] must inevitably, directly, and immediately cause the occurrence of an event kindred to imperiling the safety of a transport already at sea can support even the issuance of an interim restraining order").

4 See Stewart v. McCoy, 537 U.S. 993, 995 (2002) (Stevens, J., respecting the denial of certiorari) (noting that " $[\mathrm{w}]$ hile the requirement that the consequence be 'imminent' is jus- 
dience First Amendment, ${ }^{6}$ an obscenity First Amendment, ${ }^{7}$ an indecency First Amendment, ${ }^{8}$ a commercial speech First Amendment, ${ }^{9}$ a First Amendment that deals with public schools, ${ }^{10}$ another that deals with public employees, ${ }^{11}$ and yet another that deals with governmentfinanced speakers. ${ }^{12}$ These divisions within First Amendment law are complicated further by the Court's willingness to apply to First Amendment cases idiosyncratic interpretive and procedural rules.

The problem with these multiple First Amendments is that once one moves away from the core First Amendment political speech jurisprudence, there is no coherent theory to explain the widely varying protection of speech within the other First Amendment categories. It is clear that the protection of speech in First Amendment categories other than political advocacy falls far short of the protection offered in cases such as Brandenburg v. Ohio, ${ }^{13}$ but it is not clear why.

There are several well-rehearsed arguments defending the general concept of multi-tiered First Amendment protections, but few of these arguments relate to the specific types of speech that fall into the less-protected speech categories. Specifically, none of the arguments for multi-tiered First Amendment protection attempt to explain why the assumptions the Court makes in its political speech cases about

tified with respect to mere advocacy, the same justification does not necessarily adhere to some speech that performs a teaching function").

$5 \quad$ See Gooding v. Wilson, 405 U.S. 518, 522 (1972) (permitting governments to punish fighting words, defined as words that are likely to cause injury or instigate an immediate breach of the peace).

6 See Edwards v. South Carolina, 372 U.S. 229, 236 (1963) (describing the circumstances under which a speaker can be arrested for antagonizing a hostile audience).

7 See Pope v. Illinois, 481 U.S. 497, 500-01 (1987) (modifying the third, artistic value component of the Miller standard); Miller v. California, 413 U.S. 15, 24 (1973) (setting forth a three-part constitutional standard for prosecuting obscene materials).

8 See FCC v. Pacifica Found., 438 U.S. 726, 750-51 (1978) (permitting the government to strictly regulate indecency on radio and television during certain parts of the day).

9 See Cent. Hudson Gas \& Elec. Corp. v. Pub. Serv. Comm'n, 447 U.S. 557, 562-63 (1980) (noting that "[t]he Constitution ... accords a lesser protection to commercial speech than to other constitutionally guaranteed expression").

10 See Bethel Sch. Dist. No. 403 v. Fraser, 478 U.S. 675, 682 (1986) (upholding sanctions against a student who used a mild double entendre in a speech at a school assembly and asserting that "the constitutional rights of students in public school are not automatically coextensive with the rights of adults in other settings").

11 See Connick v. Myers, 461 U.S. 138, 142, 147 (1983) (articulating the First Amendment standard dealing with speech by public employees, emphasizing that the protection applies primarily to speech on matters of public concern).

12 See Rust v. Sullivan, 500 U.S. 173, 192-200 (1991) (permitting the government to restrict the speech of government grantees on the grounds that, in government speech cases, grantees are speaking on behalf of the government rather than as private persons, and therefore the First Amendment does not apply).

13 Brandenburg v. Ohio, 395 U.S. 444 (1969). 
the nature of individuals and the broader society should not also apply to nonpolitical speech. The most the Court ever offers in this vein is the sort of flippant comment made by Justice Stevens in an indecent speech case, that "few of us would march our sons and daughters off to war to preserve the citizen's right to see 'Specified Sexual Activities' exhibited in the theaters of our choice." ${ }^{14}$ At first glance, this phrase seems to do little more than crystallize the Court's recognition of the common perception that some speech is inherently more valuable than other speech. Upon closer reflection, however, the notion that the government should incorporate into law popular disfavor of certain categories of nonpolitical ideas seems deeply inconsistent with the Court's general recognition in its political speech cases that the government may not engage in viewpoint or content regulation. Thus, the Court's few attempts to explain why it systematically provides less protection to some categories of speech than others is deeply unsatisfying.

This Article addresses the dilemma posed by the Court's practice of creating multiple First Amendments for different categories of speech in two ways. First, the Article will attempt to distill from the Court's political speech cases a series of propositions that seem to govern current constitutional doctrine regarding "core" political speech. This will produce something that I will call the "Brandenburg paradigm." The remainder of the Article will apply this paradigm to other categories of speech, in order to assess why the general approach to speech developed in the political speech cases should not apply to various nonpolitical speech categories as well. The Article will also address the broader theoretical and practical arguments in favor of subdividing the First Amendment into political and nonpolitical speech categories that each have different levels of protection.

The general conclusion to be drawn from this discussion is that the Court violates its own mandates from the political speech cases when it ratchets down protection for speech falling into the nonpolitical speech categories. While there are aspects of the Brandenburg paradigm that do not fit the regulatory problems that arise with regard to certain nonpolitical speech categories, in general Brandenburg can tell us a great deal about how much protection should be offered to speech having nothing to do with politics or advocacy. Brandenburg is, in the end, not really about politics, elections, or disputes about specific political policies. Brandenburg is really about defining a constitutional attitude about the proper role of intellectual freedom in

14 Young v. Am. Mini Theatres, Inc., 427 U.S. 50, 70 (1976). 
the life of each citizen living within a constitutional democracy; it is about each individual citizen's freedom from governmental constraints in all matters of the mind-even if those matters could not in any sense be classified as political.

\section{Political Advocacy AND the BRANDENBURG PARADIGM}

The basics of Brandenburg and the First Amendment right to engage in political advocacy are well known to anyone with a passing familiarity with constitutional law. The standard history of First Amendment rights offers a tale of blossoming freedom, in which the Supreme Court took less than 100 years to produce a system guaranteeing virtually absolute protection of free speech within the realm of political advocacy. The story starts before World War I, when freespeech rights essentially did not exist. The system at that time was so unprotective that the Court (including Justice Oliver Wendell Holmes) was even willing to countenance criminal convictions for the publication of tracts encouraging insignificant crimes such as public nudity. ${ }^{15}$ The story then turns to World War I, during which numerous antiwar activists and members of left-wing political parties were sent to prison for opposing American involvement in the war. The Supreme Court responded to this trend by articulating a "clear and present danger" First Amendment standard that did little to provide protection for the speech of political dissidents. The source of optimism in this period came not from the Court itself, but rather two dissenters within the Court. Justices Holmes and Brandeis produced three opinions that arguably created the structure of the modern First Amendment protection of free speech. ${ }^{16}$ These opinions articulated principles that continue to guide the Court in its modern political speech jurisprudence.

It took almost fifty years, however, for the Court to officially embrace either the spirit or the full measure of protections advocated in those Holmes and Brandeis opinions. The route to the Court's adop-

15 See Fox v. Washington, 236 U.S. 273, 275-78 (1915) (upholding a conviction for "encourag[ing] and advocat[ing] disrespect for [the] law" based on the publication of the nudist work "The Nude and the Prudes").

16 See Whitney v. California, 274 U.S. 357, 373-74 (1927) (Brandeis, J., concurring) (describing a number of restrictions on the regulation of speech under the First Amendment); Gitlow v. New York, 268 U.S. 652, 672 (1925) (Holmes, J., dissenting) (describing limitations on government regulation of speech and on the clear and present danger standard); Abrams v. United States, 250 U.S. 616, 624, 628 (1919) (Holmes, J., dissenting) (introducing an immediacy component into the clear and present danger First Amendment standard). 
tion of these opinions was convoluted. It included, for example, several opinions during the 1930s and 1940s in which the Court overturned convictions for political advocacy but without articulating clear reasons why the government had not met its constitutional burdens. ${ }^{17}$ Then, during the McCarthy era, the Court announced that it was adopting the Holmes and Brandeis approach, ${ }^{18}$ but only after articulating a constitutional standard that had little to do with Holmes and Brandeis and that provided little additional protection for the speech of the dissident political activists who most engaged the government's attention during that era. ${ }^{19}$ As the McCarthy era waned, the Court began to retreat from its broad deference to government attempts to regulate political speech, ${ }^{20}$ and by the late 1960 s the Court had provided a First Amendment foundation solid enough to support Brandenburg.

For such an important case, the Brandenburg decision is a bit of a mess, even if the facts of the case were straightforward. In Brandenburg, a member of the Ku Klux Klan made inflammatory statements about racial and religious minorities at a public rally. ${ }^{21} \mathrm{He}$ was convicted and ordered to serve one to ten years in jail under Ohio's criminal syndicalism statute, ${ }^{22}$ a statute whose legacy stretched back to the assassination of President McKinley, and whose original intent was, ironically, to stem the speech of supporters of the International Workers of the World and other radical leftists. ${ }^{23}$ The Supreme Court

17 See Thornhill v. Alabama, 310 U.S. 88, 90, 105-06 (1940) (reversing on First Amendment grounds the conviction of a labor organizer for picketing in support of a strike); Herndon v. Lowry, 301 U.S. 242, 261 (1937) (reversing on First Amendment grounds the conviction of an individual for his membership in and solicitation of members for the Communist Party); De Jonge v. Oregon, 299 U.S. 353, 365-66 (1937) (reversing on First Amendment grounds the conviction of an individual for participating in the organization of a meeting for the Communist Party).

18 See Dennis v. United States, 341 U.S. 494, 507 (1951) ("Although no case subsequent to Whitney and Gitlow has expressly overruled the majority opinions in those cases, there is little doubt that subsequent opinions have inclined toward the Holmes-Brandeis rationale.").

$19 I d$. at 510 (adopting a standard first suggested in the appellate court by Judge Learned Hand, which required the courts to gauge the "evil" advocated by the speaker against the likelihood that the evil will take place. Under such a standard, the advocacy of violent revolution is such a grave "evil" that the government will likely be allowed to suppress the advocacy even though the probability of revolution occurring is low).

20 See Yates v. United States, 354 U.S. 298, 312-327 (1957) (highlighting the Dennis standard in order to emphasize that abstract advocacy of violent revolution is protected under the First Amendment).

21 Brandenburg v. Ohio, 395 U.S. 444, 445-47 (1969).

$22 I d$. at 445.

23 For the best historical account of the development of criminal syndicalism laws, see Woodrow C. Whitten, Criminal Syndicalism and the Law in California: 1919-1927, 
overturned his conviction on free-speech grounds, in an opinion that is both murky and inelegant. The opinion was originally assigned to Justice Abe Fortas, but before he could complete it he was forced to leave the Court for financial improprieties. ${ }^{24}$ Justice Brennan completed the opinion (with a few subtle amendments that greatly increased the free-speech protections offered by the decision), and the Court issued it per curiam. ${ }^{25}$

To most observers, the important thing about Brandenburg is the First Amendment standard that the decision sets forth to govern all government efforts to regulate political advocacy. This standard is now one of the most well-established aspects of modern constitutional doctrine, but newcomers to Brandenburg may have a hard time discerning the elements of the standard from the language actually used in the opinion. The relevant phrases from the opinion assert:

the constitutional guarantees of free speech and free press do not permit a State to forbid or proscribe advocacy of the use of force or of law violation except where such advocacy is directed to inciting or producing imminent lawless action and is likely to incite or produce such action. ${ }^{26}$

This language creates a three-part standard for government regulation of political speech. The first part of the standard is drawn from the early Holmes dissents and requires that the government must show an imminent threat of harm before regulating speech. ${ }^{27}$ The second part of the standard is drawn from the early Learned Hand free speech opinion Masses Publishing Co. v. Patten ${ }^{28}$ and allows the government to prosecute speech only if the speech explicitly incites illegal action. ${ }^{29}$ The third part of the standard allows the government

TRANSACTIONS AM. PHIL. SOC'Y, March 1969, at 1, 3-4 (tracing the lineage of the criminal syndicalism statutes from the days following McKinley's assassination to the period dominated by governmental fear of the Industrial Workers of the World). Ohio passed its version of the criminal syndicalism statute in 1919. See id. at 65 .

24 See Bernard Schwartz, Justice Brennan and the Brandenburg Decision-a Lawgiver in Action, 79 JUDICATURE 24, 27-28 (1995).

$25 I d$. at 28 (“[Brennan's] changes completely altered the nature of the Brandenburg opinion, converting it from one that confirmed the clear and present danger test to one that virtually did away with the test as the governing standard in First Amendment cases.").

26 Brandenburg, 395 U.S. at 447.

27 See Gitlow v. New York, 268 U.S. 652, 672 (1925) (Holmes, J., dissenting) (describing limitations on government regulation of speech and the clear and present danger standard); Abrams v. United States, 250 U.S. 616, 628 (1919) (Holmes, J., dissenting) (introducing an immediacy component into the clear and present danger First Amendment standard).

28244 F. 535 (S.D.N.Y 1917), rev'd, 246 F. 24 (2d Cir. 1917).

29 See Gerald Gunther, Learned Hand and the Origins of Modern First Amendment Doctrine: Some Fragments of History, 27 STAN. L. REv. 719, 763 (1975) (comparing the two elements of Brandenburg and noting that the Brandenburg standard adopts the most protective elements of both the Holmes and Hand approaches). 
to prosecute only those who intend through their expression to cause harm. $^{30}$

Operating in combination, the three components of the Brandenburg standard provide virtually absolute protection of political speech-even when that speech creates an atmosphere in which harm (including violent harm) may result. In the years following Brandenburg, the Supreme Court seemed to go out of its way to emphasize that it meant what it said about protecting political speech. In Hess v. Indiana, ${ }^{31}$ for example, the Court applied Brandenburg to protect the speech of a protester yelling to a crowd " $[\mathrm{w}] \mathrm{e}$ 'll take the fucking street later" or "[w]e'll take the fucking street again" in a context where violent confrontations between police and protesters had occurred in the recent past and were likely to occur again. Likewise, in NAACP v. Claiborne Hardware Co., ${ }^{33}$ the Court applied Brandenburg to protect the speech of a political activist arguing in favor of an economic boycott of local stores by explicitly threatening his audience with phrases such as: "If we catch any of you going in any of them racist stores, we're gonna break your damn neck." ${ }^{34}$ The Supreme Court brushed off the argument that this speech was beyond the pale of legitimate political discourse by casually concluding that " $[\mathrm{s}]$ trong and effective extemporaneous rhetoric cannot be nicely channeled in purely dulcet phrases." 35

The Brandenburg/Hess/Claiborne Hardware line of cases marks a clear advance for the cause of free speech in the realm of political advocacy. By requiring the government to show both explicit incitement and a truly immediate threat of harm stemming from the speech, the Court essentially has articulated a constitutional standard that the government will almost never be able to satisfy. Subtle speakers will evade prosecution by cloaking their violent ideas in ambiguous or indirect language, and all speakers will be immune from legal liability unless the violent or illegal actions that they advocate occur precisely at the time of the speech. Any lapse in time between speech and action frees the speaker from the legal consequences of his or her advocacy. The protections offered by the standard are fur-

30 This element of the Brandenburg standard applies most often in free association cases. See Healy v. James, 408 U.S. 169, 186 (1972) ("The government has the burden of establishing a knowing affiliation with an organization possessing unlawful aims and goals, and a specific intent to further those illegal aims.").

31414 U.S. 105 (1973).

32 Id. at 107.

33458 U.S. 886 (1982).

$34 \quad$ Id. at 902.

35 Id. at 928 . 
ther enhanced by the Court's decision a decade prior to Brandenburg to treat all forms of advocacy the same-regardless of whether the advocacy related to a specifically or quintessentially political issue. ${ }^{36}$

Much of what has been said so far in this Part is a commonplace recitation of basic First Amendment doctrine relating to the constitutional protection of political advocacy. This aspect of First Amendment law is no longer terribly controversial. Brandenburg itself was decided at the end of the Warren Court era, when the Court's attentiveness to the protection of civil liberties was at its apex. Brandenburg was strongly and unanimously reaffirmed, however, in Claiborne Hardware, which was decided after a series of presidential appointments had moved the Supreme Court far to the right of its liberal Warren Court days. No one on the Court these days has expressed a desire to revisit either Brandenburg or the theory and mechanisms of protecting political advocacy that the case inaugurated.

Although the mechanics of Brandenburg and its progeny are the usual focus of articles and cases dealing with the protection of political advocacy, there are other aspects of the Court's political advocacy decisions that give those cases a resonance beyond the political context. These deeper aspects of the Court's political advocacy decisions relate to the Court's attitude toward the connection between speech and action, the proper relationship of a citizen and the government, and the way in which regulatory authorities should be allowed to interpret and control the expression of those acting outside society's mainstream. Considered together, these broader attitudes form what I term the Brandenburg paradigm. The real importance of Brandenburg and its political-speech ilk lies in the components of this paradigm, rather than in the mechanics of the doctrine relating to the regulation of political advocacy. The components of the paradigm are more important than the doctrine itself because the paradigm provides a theory of free speech that is relevant beyond the precise context of Brandenburg. Because the paradigm offers a theory of freespeech that applies beyond the realm of simple political advocacy, however, it raises the dilemma addressed in this Article: If the Court believes so strongly in certain precepts of free speech, then why does the Court refuse to apply those precepts in so many different areas of First Amendment law? To put the question more specifically: Does

36 Kingsley Int'l Pictures Corp. v. Regents of the Univ. of the State of N.Y., 360 U.S. 684, 689 (1959) ("[The Constitution's] guarantee is not confined to the expression of ideas that are conventional or shared by a majority. It protects advocacy of the opinion that adultery may sometimes be proper, no less than advocacy of socialism or the single tax.”). 
the Court's various explanations for not applying its own paradigm of free speech outside the political speech area make sense?

The remainder of this Part will identify and briefly describe the eight major components of the Brandenburg paradigm. The next Part will investigate several areas of non-political speech, in which the Court provides significantly lower levels of protection for speech and refuses to apply several different aspects of the Brandenburg paradigm. In the final Part, I will offer a brief argument for applying the Brandenburg paradigm far more extensively in First Amendment jurisprudence than the Court is currently willing to countenance.

\section{A. The Components of the Brandenburg Paradigm}

The eight components of the Brandenburg paradigm are: (1) the requirement of absolute ideological agnosticism; (2) the harm principle; (3) the immediacy requirement; (4) the assertion of high collective risk tolerance; (5) the immunization of speakers for most responses of listeners; (6) the assumption of listener incredulity; (7) the proposition that form and content are indistinguishable; and (8) the principle that the identified dangers posed by speech should be redressed by censorship only if there is no other option. Each of these components of the Brandenburg paradigm can be found in the Court's political speech cases, and some can also be found in the Court's decisions discussing the rules on government regulation of the content and viewpoint of speech-which often refer to the Court's political speech doctrine as the source of the rules that government regulation of speech is always impermissible (if based on viewpoint) or almost always impermissible (if based on content). ${ }^{37}$ The discussion below will draw on these cases to flesh out the eight components of the Brandenburg paradigm and the Court's general view of the role that speech should play in a world governed by the First Amendment.

\section{Absolute Ideological Agnosticism}

The heart and soul of the Brandenburg paradigm is the central precept that the government cannot regulate speech simply because

37 See Rosenberger v. Rector \& Visitors of the Univ. of Va., 515 U.S. 819, $828-29$ (1995) ("It is axiomatic that the government may not regulate speech based on its substantive content or the message it conveys.... When the government targets not subject matter, but particular views taken by speakers on a subject, the violation of the First Amendment is all the more blatant. ... Viewpoint discrimination is thus an egregious form of content discrimination."). 
the government disagrees with the content of the speech or the point of view of the speaker. In a world governed by a First Amendment that is organized around the principles established in Brandenburg, government is an agnostic entity. This does not mean that the government can never take a point of view about political matters; of course, the government will express a point of view about political matters all the time. The government is a political entity, and virtually all of its actions that advance a particular policy will also express a political viewpoint. The Brandenburg paradigm typically applies not to those within the government advancing the government's own perspectives, but rather to actions taken by those within the government to regulate, forestall, or prevent the speech of opponents outside the government. The Brandenburg paradigm erects a solid wall between the public and private sectors in the sense that there are very different constitutional rules governing what the government itself is allowed to do or say on its own behalf as opposed to what the government is allowed to impose on the expression of private actors.

Justice Jackson's famous axiom aptly describes the Brandenburg paradigm's mandate regarding how the government should view the private sector: "If there is any fixed star in our constitutional constellation, it is that no official, high or petty, can prescribe what shall be orthodox in politics, nationalism, religion, or other matters of opinion or force citizens to confess by word or act their faith therein." 38 Several things are notable about this famous quote. First of all, it predated Brandenburg by several decades. Thus, the notion that the government is precluded from prescribing "good" ideas and punishing the utterance of "bad" ideas has been with us in First Amendment jurisprudence for a very long time. Secondly, Justice Jackson does not limit his protection of speech to ideas that are overtly political. His concept of protected opinions includes "politics, nationalism, religion, or other matters of opinion." In other words, any topic on which people might have an opinion is covered by the First Amendment. Along the same lines, the Court greatly expanded the range of topics included in the category of constitutionally protected advocacy long before Brandenburg put teeth into the constitutional rules governing advocacy. ${ }^{39}$

The third significant aspect of Justice Jackson's statement of constitutionally mandated agnosticism is that it does not contain an escape clause for the government, such as the notion that the govern-

38 W. Va. State Bd. of Educ. v. Barnette, 319 U.S. 624, 642 (1943).

$39 \quad$ See Kingsley Int'l Pictures Corp., 360 U.S. at 689. 
ment may regulate ideas because they are immoral, socially useless, or perceived as dangerous by representatives of the status quo. All ideas are protected-not just the safe or morally benign ones. Likewise, there is no room for the sort of cost-benefit analysis that is sometimes proposed as a way of melding considerations of civil liberties with the need for various forms of social and economic regulation. ${ }^{40}$ Justice Jackson's statement therefore dovetails with the central conception of the Brandenburg paradigm that, in the absence of proof that speech will lead directly to a concrete, identifiable harm of the sort that the government may redress, speech may not be regulated at all.

The notion that the government must remain agnostic when exercising its legal authority regarding the speech of its citizens is now deeply embedded within the First Amendment jurisprudence of the Supreme Court and is often stated as a general proposition that applies across the board of First Amendment concerns. In one variation on this theme, Justice Kennedy once wrote for the Court that "[v]iewpoint discrimination is ... an egregious form of content discrimination. The government must abstain from regulating speech when the specific motivating ideology or the opinion or perspective of the speaker is the rationale for the restriction." ${ }^{41}$ This proposition is often combined with other First Amendment mechanisms, such as the overbreadth doctrine, to overturn statutes that on their face seem to distinguish between the government's favorite ideas and other ideas that the government seeks to disparage. ${ }^{42}$

In short, the first component of the Brandenburg paradigm is a potent tool in restricting those who control the government from using the government's coercive authority to direct public debate in a direction that they favor. In easy cases, especially those involving the

40 For different versions of the cost/benefit argument, see CASS R. SUNSTEIN, DEMOCRACY AND THE PROBLEM OF FrEE SPEECH 28-51 (1993) (arguing that speech should be regulated under much the same standard that applies to other targets of government regulation); R. H. Coase, The Economics of the First Amendment: The Market for Goods and the Market for Ideas, 64 AM. ECON. REv. 384 (1974) (arguing that the market for speech and the market for commercial goods should be governed by the same analysis); Richard A. Posner, Free Speech in an Economic Perspective, 20 SUFFOLK U. L. REV. 1 (1986) (setting forth an economic model for the regulation of free speech); Richard A. Posner, Pragmatism Versus Purposivism in First Amendment Analysis, 54 STAN. L. Rev. 737 (2002) (arguing that a pragmatic cost-benefit analysis is consistent with First Amendment history, theory, and text)

41 Rosenberger, 515 U.S. at 829 (striking down student activity funding regime at a public university that discriminated against some student groups based on the subject matter of their speech).

42 See R.A.V. v. City of St. Paul, 505 U.S. 377 (1992) (striking down a St. Paul, Minnesota hate speech ordinance on the ground that it discriminated on the basis of both content and viewpoint). 
overt regulation of political speech, this is how Brandenburg is typically used. Outside the realm of political speech, however, in recent years the Court has become far more reluctant to force the government to refrain from regulating the marketplace of ideas. Part II will explore several instances of this phenomenon.

\section{The Harm Principle}

Under the first component of the Brandenburg paradigm, the government is generally prohibited from using its regulatory authority to dictate the terms or content of public debate about both political and nonpolitical matters. Even when dealing with the most highly protected forms of speech, however, there is an exception to the general mandate of government agnosticism. The exception applies when the speech in question threatens to cause an immediate, concrete, and identifiable harm to property, institutions, or individuals other than the speaker. Thus, at least with regard to the regulation of speech, the Court has effectively adopted a version of John Stuart Mill's harm principle: "the only purpose for which power can be rightfully exercised over any member of a civilized community, against his will, is to prevent harm to others. His own good, either physical or moral, is not a sufficient warrant." ${ }^{43}$ Louis Brandeis, one of the key progenitors of what has become the Brandenburg paradigm, tightened the Millian harm principle even further by prohibiting the government from regulating speech that causes only minor harms: "There must be reasonable ground to believe that the evil to be prevented is a serious one."

In addition to prohibiting the government from regulating anything but harmful speech, the Court has also been rigorous in limiting the definition of the concept of "harm." In the political advocacy realm, the Court has strictly limited the government to regulating only speech that leads to concrete, and probably only physical, harms. In all three of the Court's main political speech cases, the Court focused on the harm of physical violence or public disorder. ${ }^{45}$ These

43 John Stuart Mill, On Liberty 68 (Gertrude Himmelfarb ed., Penguin Books 1985) (1859).

44 Whitney v. California, 274 U.S. 357, 376 (1927) (Brandeis, J., concurring).

45 See NAACP v. Claiborne Hardware Co., 458 U.S. 886, 928 (1982) ("When [emotional appeals to unity and action in a common cause] do not incite lawless action, they must be regarded as protected speech."); Hess v. Indiana , 414 U.S. 105, 109 (1973) (per curiam) (maintaining that in the absence of evidence that the speaker's words "were intended to produce, and likely to produce, imminent disorder, those words could not be punished by the State on the ground that they had a 'tendency to lead to violence'”); Brandenburg v. 
cases and their predecessors make clear that no abstract, ideological, emotional, or otherwise intangible harms would suffice to justify the regulation of advocacy. As Justice Harlan once famously noted, "[t]he essential distinction is that those to whom the advocacy is addressed must be urged to do something, now or in the future, rather than merely to believe in something."

In these cases the Court has protected advocates ranging from communists to $\mathrm{Ku}$ Klux Klansmen. The facts in these cases indicate that even the prospect that the speaker will lead his or her listeners to believe in a set of ideas that are odious, extremist, or far outside the mainstream is insufficient to justify government regulation of speech. Thus, within the Brandenburg paradigm the harm principle is closely linked to the agnosticism mandate. By limiting the range of harms that the government can use to justify regulating speech, the Court effectively insulates against government coercion the full range of individual perspectives about the world. Thus, in the absence of proof that the speaker is directly inciting violence or other illegal activity, the government is not allowed to use its legal authority in a communitarian fashion to construct a preferred set of social mores to which its citizens must give obeisance. The government is not allowed to force its citizens to pledge allegiance to itself because, in the realm of the Brandenburg paradigm, opposition to the government is not a legally cognizable harm.

\section{The Imminence Requirement}

The imminence requirement further limits the government's ability to regulate radical political advocacy by stipulating that the speaker being regulated must not only create a harm, but an imminent harm. Recall the language in Brandenburg: proscribable advocacy must be "directed to inciting or producing imminent lawless action and is likely to incite or produce such action." 47 The imminence requirement stems back to debates within the Court after World War I over the prosecutions of socialist and anarchist opponents of the war. The position of the Court's majority at the time was summarized by Justice Sanford in his majority opinion in Gitlow v. New York. ${ }^{48}$ Justice

Ohio, 395 U.S. 444, 447 (1969) (prohibiting the government from punishing advocacy of force or violence unless "such advocacy is directed to inciting or producing imminent lawless action and is likely to incite or produce such action").

46 Yates v. United States, 354 U.S. 298, 324-25 (1957).

47 Brandenburg, 395 U.S. at 447 (emphasis added).

48268 U.S. 652 (1925). 
Sanford argued that the government should be allowed to punish radical political advocacy even when "the effect of a given utterance cannot be accurately foreseen." ${ }^{49}$ Justice Sanford's metaphor for revolution was a firestorm; in his view, the government should be allowed to extinguish the revolutionary spark "without waiting until it has enkindled the flame or blazed into the conflagration." the government did not have to prove that speech being targeted for suppression had any immediately cognizable or concrete illegal consequences, this standard had the effect of allowing the government to suppress virtually any abstract advocacy that deviated significantly from the political status quo.

Following the lead of Justices Holmes and Brandeis, the modern Court has resoundingly rejected Justice Sanford's conception of governmental power to regulate radical political advocacy. Indeed, the introduction of an imminence requirement is the major doctrinal innovation of Justice Holmes's famous dissenting opinion in Abrams $v$. United States - an opinion that many years later would contribute a great deal to the holding of Brandenburg and would likewise form the heart of the Brandenburg paradigm. The introduction of an imminence requirement was necessary to salvage Holmes's favored contextual analysis for free-speech protection under the First Amendment. In the guise of Holmes's famous clear and present danger test, the contextual analysis had proved virtually worthless in protecting political dissidents during times of heightened domestic tensions over the war and prejudice against both immigrants and left-wing radicals. ${ }^{51}$

The importance of the imminence requirement to Holmes is evidenced by his phrasing of the requirement in Abrams: "we should be eternally vigilant against attempts to check the expression of opinions that we loathe and believe to be fraught with death, unless they so

$49 \quad I d$. at 669 .

$50 \quad I d$.

51 All of the Supreme Court's early cases in which it applied the clear and present danger analysis involved some combination of those two elements. See Whitney v. California, 274 U.S. 357 (1927) (upholding the conviction of a member of the Communist Labor Party for attending a party convention); Gitlow, 268 U.S. at 657-59 (upholding the conviction of a member of the Socialist Party for distributing a pamphlet calling for "revolutionary mass action"); Abrams v. United States, 250 U.S. 616 (1919) (upholding convictions of five Russian immigrants, self-identified as "anarchists" or "socialists," for distributing antiwar circulars); Debs v. United States, 249 U.S. 211 (1919) (upholding the conviction of the head of the American Socialist party for giving a speech criticizing American involvement in World War I); Frohwerk v. United States, 249 U.S. 204 (1919) (upholding the conviction of a German newspaper editor for publishing editorials against the American involvement in World War I); Schenck v. United States, 249 U.S. 47 (1919) (upholding the conviction of Socialist party activists for distributing antiwar pamphlets). 
imminently threaten immediate interference with the lawful and pressing purposes of the law that an immediate check is required to save the country. ${ }^{52}$ As the son of a prominent American poet, and as a writer of no small talent himself, it is a measure of the importance of the imminence requirement that Holmes used some variation of the term three times in one sentence in describing what should be the constitutional standard for regulating political speech. His description of the standard also gives an indication of how imminent a harm must be to satisfy the Constitution: the standard covers the expression of opinions that are "fraught with death," and such opinions can only be squelched if "an immediate check is required to save the country." According to Holmes, nothing less than the threat of the country's destruction could justify the suppression of political speech. A similar theme can be found in Justice Brandeis's opinion eight years later in Whitney v. California, in which Brandeis articulated a sort of time-frame analysis to determine whether the government had satisfied the imminence requirement. According to Brandeis, "[i]f there be time to expose through discussion the falsehood and fallacies, to avert the evil by the processes of education, the remedy to be applied is more speech, not enforced silence. Only an emergency can justify repression." ${ }^{53}$ Both the Holmes and Brandeis formulations of the imminence requirement would require the government to walk right up to the precipice of social disorder before suppressing the speech of its opponents. The modern Court seems to take these formulations to heart. In Claiborne Hardware, for example, the Court protected speech that occurred in the context of ongoing violence, noting simply that the violence did not occur immediately following the speech. ${ }^{54}$ In Hess, likewise, the Court protected a speaker who was urging the crowd that had already engaged in violence to become violent again. ${ }^{55}$ Brandeis's time-frame analysis now seems to be a central part of modern First Amendment jurisprudence.

The imminence requirement is not simply a mechanism for enforcing the other aspects of the Brandenburg paradigm; it is intricately intertwined with the agnosticism mandate. When he objects to Holmes's immediacy analysis in Gitlow, Justice Sanford approaches

52 Abrams, 250 U.S. at 630 (Holmes, J., dissenting) (emphasis added).

53 Whitney, 274 U.S. at 377 (Brandeis, J., concurring).

54 See NAACP v. Claiborne Hardware Co., 458 U.S. 886, 928 (1982) ("In this case . . —with the possible exception of [one] incident-the acts of violence identified in 1966 occurred weeks or months after the April 1, 1966, speech ....”).

55 See Hess v. Indiana, 414 U.S. 105 (1973) (per curiam) (overturning the conviction of a protester who urged crowd to "take the fucking street later" or "take the fucking street again") 
the question from the perspective of the government's right of selfpreservation; according to Justice Sanford, a government should not be forced to defer the implementation of self-preservation measures until the point at which there is an "imminent and immediate danger of its own destruction." ${ }^{56}$ Holmes's response to Justice Sanford's concern with government self-preservation is to argue that under his theory of free speech, no government necessarily deserves to be preserved in the face of political opposition. In Holmes's more pithy phrasing of this point, "[i]f in the long run the beliefs expressed in proletarian dictatorship are destined to be accepted by the dominant forces of the community, the only meaning of free speech is that they should be given their chance and have their way." ${ }^{57}$

If one takes this phrase literally, then the clear impression in reading Holmes's free-speech opinions is that his own deep-seated political skepticism (which some would go so far as to label nihilism ${ }^{58}$ ) is so strong that he would actually prohibit the government from saving itself in times of political crisis. Whether the modern Court would take the same radically skeptical view of governmental power is doubtful. But it does seem clear that the modern Court would adhere to Brandeis's notion that only an emergency would justify the suppression or punishment of speech. It is equally clear that the Brandenburg paradigm is permeated with Holmesian skepticism about unsupported government claims of political danger. In the absence of concrete facts leading to the clear implication of violence or other serious threats to the social order, speech coming within the Brandenburg paradigm cannot be suppressed by the government.

\section{The Assertion of High Collective Risk Tolerance}

When the Court settled the debate over the imminence requirement in favor of a standard that allows the government to suppress speech only in the face of a dire emergency, the Court simultaneously adopted a particular perspective about society's tolerance for political risk. In essence, the Brandenburg paradigm adopts the perspective that this society is willing to tolerate significant amounts of social turmoil as part of our daily social fabric. Moreover, according to the Brandenburg paradigm, society must tolerate a significant amount of

Gitlow, 268 U.S. at 669.

$I d$. at 673 (Holmes, J., dissenting).

See, e.g., David Luban, Justice Holmes and the Metaphysics of Judicial Restraint, 44 DuKE L.J. 449, 475 (1994) ("Holmes qualifies as a moral nihilist; indeed, he advanced the moral nihilist's typical reduction of value judgments to tastes and naked preferences ...."). 
speech by those who are recognized as far outside the mainstream of society and the "legitimate" political culture. There is no pretense here that we are talking about a marketplace of ideas; no one seriously contends that the Klansmen whose claims were at issue in Brandenburg have anything worthwhile to contribute to public debate about the significant issues of the day. Speakers such as the Klansmen in Brandenburg are little more than pesky nuisances and undifferentiated threats to the public order. The question, therefore, is at what point can society simply shut such people up? According to the Brandenburg paradigm, the answer to that question is that we must wait until serious physical disorder occurs; distaste for the speaker or vague portensions of where the speaker's ideas may lead are not sufficient. One of the central lessons of the Brandenburg paradigm is that it prohibits society from acting against speakers on the basis of mainstream society's political squeamishness.

As with most issues regarding the political speech protections of the First Amendment, there are two possible explanations for this approach, and both of the explanations stem back to the very different personalities of those strange First Amendment bedfellows, Holmes and Brandeis. On the one hand, one could argue, à la Brandeis, that the Court has imposed on society such a high level of risk tolerance because the Court is forcing us to mimic the brave Framers, who in Brandeis's estimation "did not fear political change [and] did not exalt order at the cost of liberty." ${ }^{59}$ Or, conversely, one can take Justice Holmes's que sera, sera approach that society must tolerate Bolsheviks and other radicals simply because they might just prevail in the end and abstract democratic theory requires us to be open to that possibility. ${ }^{60}$ Under this approach, risks are not bad things, because they are simply part of history's cycle.

Under either the Brandeis or the Holmes rationale, the bottom line is that the First Amendment jurisprudence that those Justices set in motion creates a constitutional mandate that society must be open to all political ideas, including those that advocate destroying the very political structure that allows such ideas to be expressed. As with the definition of harm, the Brandenburg paradigm narrows the conception of risk that society is allowed to use in justifying the application of force against political opponents. Social disorder, political change, vociferous debate, the undermining of traditional values, or even threatened change in the very nature of government itself are

59 Whitney v. California, 274 U.S. 357, 377 (1927) (Brandeis, J., concurring).

60 See Gitlow, 268 U.S. at 673 (Holmes, J., dissenting). 
not even counted as cognizable risks of the Brandenburg paradigm. The only risk that counts under the Brandenburg paradigm is risk that takes the form of immediate, violent social change in a context in which debate is forestalled by the rapid development of social disorder.

\section{The Immunization of Speakers for the Actions of Listeners}

The fifth component of the Brandenburg paradigm is more pragmatic than the previous four components. The fifth component deals with how the Brandenburg paradigm is actually implemented in situations where speakers lead listeners to do something antisocial, violent, or illegal. The logical implication of the Brandenburg paradigm is that speakers are immunized from legal liability for the nonimmediate actions that their speech may have instigated in their listeners. Of course, this rule may be overcome by evidence of more direct involvement between speakers and listeners (as in a criminal conspiracy, for example). Yet in those cases, more than speech is involved, and therefore the matter is considered outside the Brandenburg paradigm. In the absence of such additional evidence, the simple fact that a speaker gave an inflammatory speech is not a sufficient legal justification to hold that speaker accountable for the actions of the speaker's audience.

The application of this component of the Brandenburg paradigm leads to some of the Court's most controversial decisions. Two of the cases that serve as the foundation for the Brandenburg paradigm provide examples of this phenomenon. In Claiborne Hardware, for example, the Court protected the speech of someone who instigated a crowd in the context of a long-running, acrimonious, and often violent economic boycott of local businesses. ${ }^{61}$ The speech was overtly threatening to those who violated the boycott, in an atmosphere where the boycotters had actually posted individuals outside of local businesses to identify those who broke the boycott. ${ }^{62}$ Likewise, in Hess, an individual walked back and forth in front of a roiling crowd. Some members of the crowd had most likely already participated in violent activities, and he verbally urged them to once again behave illegally and possibly violently. ${ }^{63}$ In both of these cases, it is not diffi-

\footnotetext{
61 See NAACP v. Claiborne Hardware Co., 458 U.S. 886, 898-906 (1982) (reviewing the seven-year history of the dispute between the NAACP and local businesses).

62 See id. at 903-04 (discussing the use of store watchers known as "Black Hats").

63 See Hess v. Indiana, 414 U.S. 105, 107 (1973) (per curiam) (although there is no dispute that the words used by Hess were either "we'll take the fucking street later" or "we'll take
} 
cult to arrive at the intuitive conclusion that the lower courts did nothing wrong in refusing to protect the speech. Both situations involved a strong threat of violence, and perhaps even mayhem or death. Both situations involved speakers who seemed to be fully aware of the consequences of their speech. And both situations involved speakers who were using their speech to engage the enemy through physical action or violence, not words or intellect.

Despite these factors, the Court easily found that the First Amendment protected the speakers in each instance. The narrow historical rationale for this is easy to discern. The modern Court is extremely reluctant to attribute any crowd's violent tendencies to a speaker in an historical context in which an earlier Court was willing to allow the government to imprison (as Holmes put it in Abrams) virtually every "poor and puny anonymit[y]"64 who was caught while uttering an anti-government phrase in public. The lesson that these early cases have taught the modern Court is not just that "[s] trong and effective extemporaneous rhetoric cannot be nicely channeled in purely dulcet phrases, ${ }^{\prime 65}$ but that if you give the government its head, even purely dulcet phrases can sometimes subject opposition presidential candidates to ten years in federal prison. ${ }^{66}$ Immunizing the speaker from responsibility for all non-immediate violent actions committed by the speaker's audience has the effect of removing from the government the ability to interpret benign political opposition as the incitement of violence.

Each component of the Brandenburg paradigm reinforces one or more of the others. This particular aspect of the paradigm dovetails with the seventh component of the paradigm discussed below: if the government is prohibited from using a speaker's aggressive phrasing and presentation as the instigation of violence, the speaker is freed to speak as forcefully as he or she sees fit. In the Brandenburg paradigm, speakers and speakers alone can decide how to phrase their particular point of view. The phrase "I respectfully oppose the draft" may reflect the same sentiments as "Fuck the draft," $"$ but rhetorically speaking the two phrases are in different leagues. Under the Bran-

the fucking street again," there is some dispute as to whether Hess actually intended to incite the crowd).

64 Abrams v. United States, 250 U.S. 616, 629 (1919) (Holmes, J., dissenting).

65 Claiborne Hardware, 458 U.S. at 928.

66 See Debs v. United States, 249 U.S. 211, 217 (1919) (upholding the ten-year prison sentence issued to Socialist Party presidential candidate Eugene V. Debs for giving a campaign speech opposing American involvement in World War I).

67 See Cohen v. California, 403 U.S. 15, 16 (1971) (overturning the conviction of a man for wearing a jacket bearing the inscription "fuck the draft" in a public courthouse). 
denburg paradigm, each speaker may decide for him or herself how much verbal aggression is necessary for the occasion, regardless of whether the more aggressive speech may instigate others to act in illegal ways.

\section{The Assumption of Listener Incredulity}

In addition to the lesson that speakers should be allowed to decide for themselves how to cast their ideas, the Court has learned an additional lesson from its supine disinclination to protect dissent during the World War I era. This additional lesson has to do, not with the rights of speakers, but rather with the responsibilities of listeners. The earlier era of First Amendment jurisprudence, during which the Court permitted the government to suppress political dissent virtually without constitutional constraint, produced several consequences for members of the intended audience for the suppressed speakers. The most obvious consequence is that the listeners could not hear particular ideas and points of view. Thus, the scope of public debate was warped to favor the government's preferred perspective. The less obvious consequence is that these cases freed listeners from the responsibility of deciding what to believe and what not to believe and also freed them from the obligation to exercise restraint and to obey the law in the face of overt entreaties to do otherwise. Each of these consequences is overtly paternalistic. During this period, the government acted expressly on the belief that individual citizens were incapable of figuring out for themselves what they believed about major public controversies of the day and of obeying the law in the face of incitements to disobey.

Paternalism is in general a dangerous precept for a democratic government. All forms of democracy are predicated on notions of popular rule; thus, all forms of democratic government assume that the people run the government instead of the other way around. A government that engages in paternalistic behavior toward its citizenry forsakes the central characteristic necessary for that government to be characterized as democratic. A democratic government obtains its legitimacy only through the consent of the governed. A government that engages in paternalistic manipulation of public debate effectively seeks to create its own consent by denying its citizens access to political options that do not favor (or may even undermine) the current regime. A government that manipulates its own citizenry in this fashion cannot lay claim to democratic legitimacy.

The Brandenburg paradigm addresses these issues in several ways. First, as discussed in the previous Sections, the Brandenburg paradigm 
protects democratic governments from acceding to their natural inclination to err on the side of safety with regard to radical political expression. Under the Brandenburg paradigm, nothing short of an immediate threat of violent upheaval or revolution will justify shutting down the speech of the government's political opponents.

The second way in which the Brandenburg paradigm addresses these issues may be even more important: implicit in the Brandenburg paradigm is an image of a proper democratic citizen. The paradigm imputes to that citizen a certain number of characteristics that are essential to effective participation in a political system governed by the First Amendment. Those characteristics include incredulity, rationality, critical intelligence, insensitivity to political slights, and an understanding of the political protocols that accompany an orderly transfer of power, leavened with a Jeffersonian awareness ${ }^{68}$ that orderly political processes may ossify to the point that precepts of liberty will compel citizens to overthrow the existing order and begin again. These characteristics effectively transfer from the government to individual citizens the responsibility for avoiding the political excesses threatened by radical political and religious ideologues. The Brandenburg paradigm assumes that citizens approach political discourse with an attitude of healthy skepticism and that they assume that everything said in the political marketplace is half-true, altogether false, or at least entirely self-interested. Likewise, the Brandenburg paradigm's assumption that citizens will bring to the political marketplace the characteristics of rationality and critical intelligence leads to the conclusion that citizens are fully capable of detecting snake oil in the form of factual claims that are demonstrably untrue. The Brandenburg paradigm assumes that citizens are fully capable of dealing with the public dissemination of nonsense ranging from Holocaust denial to creationism without the government's protection. Thus, while other constitutional provisions such as the Equal Protection Clause or the Establishment Clause may preclude the government itself from making such claims, there is no need to regulate the private market in the expression of factual nonsense.

In short, the Brandenburg paradigm transforms the First Amendment into an anti-paternalism clause. Under Brandenburg, citizens tate that Governments long established should not be changed for light and transient Causes .... But when a long Train of Abuses and Usurpations, pursuing invariably the same Object, evinces a Design to reduce [the people] under absolute Despotism, it is their Right, it is their Duty, to throw off such Government, and to provide new Guards for their future Security."). 
may need the government's protection when radical speech turns into a riot, but until that point, citizens are fully capable of taking care of themselves.

\section{Form and Content Are Constitutionally Indistinguishable}

The central precept of the Brandenburg paradigm is that the government is not allowed to censor ideas that contradict the government's official perspective on politics, morality, or other aspects of the social ethos. This precept generates a corollary regarding the government's authority for dictating how ideas may be presented to the world. According to the Brandenburg paradigm, the government has no authority to dictate the tone of speech, moderate the forcefulness of speech, or in any other way force speakers to present their ideas in one way rather than another. To put the matter simply, if the First Amendment is viewed through the prism of the Brandenburg paradigm, form is indistinguishable from content.

The primary support for this component of the Brandenburg paradigm is Cohen $v$. California, ${ }^{69}$ a case often viewed as more famous for its facts than for what it adds to First Amendment jurisprudence. Cohen is, of course, the case in which an individual was convicted of violating a California statute prohibiting anyone from disturbing the peace by "offensive conduct." The individual in question violated the statute by wearing around the Los Angeles County Courthouse a jacket inscribed with the phrase "Fuck the Draft." "The Supreme Court overturned the conviction, holding that the inscription was a constitutionally protected expression of opinion.

In cataloguing the various arguments California made for upholding the conviction, the Court settled on the state's primary argument, which the Court viewed as the state's desire "to maintain what they regard as a suitable level of discourse within the body politic." ${ }^{\text {"1 }}$ The Court rejected this argument on both practical and theoretical grounds. Practically, the Court could not discern any difference between this particular epithet and others, leading to Justice Harlan's quip that "one man's vulgarity is another's lyric."72 The Court's theoretical ground for rejecting the state's argument was that expressive form and content are inextricably intertwined and therefore are both protected by the First Amendment. The Court rejected California's

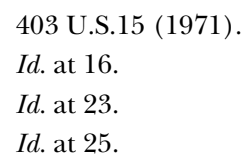


effort to impose decorum rules on public speech by specifically linking a speaker's choice of words to the speaker's decision about which ideas to express. Just as the First Amendment does not permit the government to dictate the content of the speaker's ideas, the government also cannot dictate the speaker's mode of expressing those ideas: "we cannot indulge the facile assumption that one can forbid particular words without also running a substantial risk of suppressing ideas in the process. Indeed, governments might soon seize upon the censorship of particular words as a convenient guise for banning the expression of unpopular views." ${ }^{\text {,3 }}$

It is the Court's willingness to link expressive form and content that gives Cohen its continued significance within First Amendment jurisprudence and makes the decision one of the cornerstones of the Brandenburg paradigm. But there is another aspect of the Cohen decision that may be even more significant in terms of the way the Court interprets human expression and how that expression must be protected under the First Amendment. In one paragraph of his Cohen majority opinion, Justice Harlan notes the "dual communicative function" served by expression: "[expression] conveys not only ideas capable of relatively precise, detached explication, but otherwise inexpressible emotions as well. In fact, words are often chosen as much for their emotive as their cognitive force." ${ }^{74}$ These sentiments are self-evident to writers of even the most modest talents. An op-ed article expressing in moderate terms the author's disagreement with the country's current conscription system clearly does not pack the punch of the in-your-face declaration "Fuck the Draft."

Cohen is significant in that the Court provides First Amendment protection for the emotive as well as the cognitive values of speech. Without such protection, the government would be given broad authority to inhibit the effectiveness of political speech by purporting to target only the manner rather than the content of the speaker's expression. Indeed, without such protection, each of the three primary Brandenburg paradigm cases-Brandenburg, Claiborne Hardware, and Hess - could have come out the other way. The speakers in each of these cases were communicating their ideas in aggressive, even antisocial ways, and the same ideas could easily have been communicated in much more muted terms. Under the Brandenburg paradigm, speakers are not forced to choose the least frightening or most comforting mode of communicating their beliefs. Likewise, the recogni- 
tion that the emotive value of speech is cognizable under the First Amendment extends protection to listeners who may not be primarily interested in the cognitive component of expression. Under the Brandenburg paradigm, the nonrational elements of speech are equally important as the rational elements.

The extension of First Amendment protection to the emotive elements of expression is one of the ways in which the Brandenburg paradigm has obvious implications beyond the realm of political advocacy. These implications will be explored below. For the moment, however, it is important to recognize that this aspect of the Brandenburg paradigm contributes to First Amendment jurisprudence a particular concept and vision of human beings. Under this concept, human beings are not simply robotic agents, constantly digesting information and rationally calculating the value of that information. Instead, human beings are equally prone to irrational whims and desires that often lead them in directions that the government wishesperhaps for very good reasons-they would not go. Like Plato, who feared the antisocial effects of certain music on his rationalist Republic, ${ }^{75}$ governments are naturally inclined to fear the nonrational forces that often motivate human conduct. A central point of the Brandenburg paradigm is that until antisocial conduct manifests itself, antisocial expression is immune from governmental controlregardless of how emotional or even irrational that expression may be.

\section{Censorship Is a Last Resort}

The eighth component of the Brandenburg paradigm is simply the consequence that follows inevitably from the other seven. It is worth

75 See, e.g., Plato's discussion of music in Protagoras, in which he complains that musicians "[p] ossessed by a frantic and unhallowed lust for pleasure, they contaminated laments with hymns and paeans with dithyrambs ... creat[ing] a universal confusion of forms." According to Plato, this led to the popularization of music by way of "the assumption that in music there is no such thing as a right and a wrong, the right standard of judgment being the pleasure given to the hearer, be he high or low." Plato's conclusion is that "music has given occasion to a general conceit of universal knowledge and contempt for law, and liberty has followed in their train." From there, "the next stage of the journey toward liberty will be refusal to submit to the magistrates, and on this will follow emancipation from the authority and correction of parents and elders; then, as the goal of the race is approached, comes the effort to escape obedience to the law, and, when that goal is all but reached, contempt for oaths, for the plighted word, and all religion. The spectacle of the Titanic nature of which our old legends speak is re-enacted; man returns to the old condition of a hell of unending misery." PLATO, LAWS, bk. III, 700a-701c, in THE COLLECTED Dialogues of Plato INCLUding THE LeTters 1294-95 (Edith Hamilton \& Huntington Cairns eds., Lane Cooper et al. trans., 1961). 
separating this precept into its own category, however, because in some ways this is the heart of the Brandenburg paradigm. The basic idea is encapsulated by the central passage from Justice Brandeis's Whitney concurrence: "If there be time to expose through discussion the falsehood and fallacies, to avert the evil by the processes of education, the remedy to be applied is more speech, not enforced silence. Only an emergency can justify repression." ${ }^{76}$ Every aspect of the Brandenburg paradigm is oriented toward deferring to the intellect of the citizenry and preventing the government from getting involved in the marketplace of ideas until the government, quite literally, has no other option to avoid immediate violent social upheaval or revolution. If there is any other alternative to censorship, the Brandenburg paradigm requires the government to take it.

Multiple implications follow from the notion that censorship must be used only as a last resort. Among other things, given the Brandenburg paradigm's insistence on an "emergency-only" justification for censorship, several avenues are directly foreclosed to the government. First, the Brandenburg paradigm does not permit the government to engage in preemptive restrictions on the dissemination of information or ideas. The government cannot decide in advance that certain ideas (for example, communist or racist ideas) are too dangerous for the public to hear. Likewise, the government cannot decide in advance that certain information (for example, bomb-making information) is too dangerous for the public to hear.

Second, the Brandenburg paradigm does not permit the courts to defer to the political branches in determining whether some ideas or information should be suppressed for reasons of public safety or national security. It does not matter whether such deference is cast in terms of deference to the greater expertise in the political branches (as in Justice Sanford's Gitlow opinion ${ }^{77}$ or Justice Jackson's opinion in Dennis v. United States ${ }^{78}$ ) or as a matter of separation of powers (as in Justice Frankfurter's opinion in Dennis ${ }^{79}$ ). In all instances, the

76 Whitney v. California, 274 U.S. 357, 377 (1927) (Brandeis, J., concurring).

77 See Gitlow v. New York, 268 U.S. 652, 668 (1925) (reviewing a New York state syndicalism statute and concluding that "[e]very presumption is to be indulged in favor of the validity of the statute" (citation omitted)).

78341 U.S. 494, 568-69 (1951) (Jackson, J., concurring) (arguing that existing First Amendment standards should be applied only to cases involving isolated instances of speech and "trivialities," and that the Court should not "hold our Government captive in a judge-made verbal trap" in the face of "a well-organized, nation-wide conspiracy").

79 Id. at 525 (Frankfurter, J., concurring) (arguing that courts are ill-suited to judge cases involving conflicts between "competing political, economic and social pressures" and 
Brandenburg paradigm does not permit the political branches to deny citizens the right to hear and consider all political options.

Finally, the Brandenburg paradigm does not permit the government to engage in a cost-benefit analysis for different examples of speech. Under the Brandenburg paradigm, the cost-benefit analysis has already been made by the Constitution itself. This system embodies what Holmes once characterized as an "experiment," through which we "wager our salvation" $" 80$ on the notion that people will have enough common sense to sort out for themselves the good information and ideas from the bad. But this wager is not as cavalier as it may at first seem. It is based on a theoretical approach to government that is informed by Holmes's particularly jaded perspective toward all collective human action. The Brandenburg paradigm rejects a costbenefit analysis for speech because the very terms "cost" and "benefit" are tendentious. If the government is allowed to make such an analysis in order to decide whether to regulate speech, it will always do so for the benefit of those who control the government. Charter members of the status quo can be counted on to see plenty of costs but no benefits in expression that proposes to upset the status quo. For this reason, the Brandenburg paradigm does not permit the status quo to decide its own fate. This wager on popular control may result not only in "verbal cacophony," ${ }^{81}$ but also violent social or political upheaval. As Holmes once noted, as long as the First Amendment "experiment" is in the Constitution, the government is not allowed to prevent the dissemination of opinions that we "loathe and believe to be fraught with death," 82 unless the country's very existence is at stake. That, in its purest essence, is the Brandenburg paradigm.

\section{B. The Brandenburg Paradigm and the Democratic Citizen}

The Brandenburg paradigm has its origins in the Court's political speech cases, but the paradigm has implications that range far beyond politics. The Brandenburg paradigm is not just a series of rules about regulating political policy discussions, but rather comprises an entire worldview about people and how they relate to each other and their government. This worldview incorporates models of both governments and citizens that are directly relevant to government regu-

concluding that " $[\mathrm{p}]$ rimary responsibility for adjusting the interests which compete in the situation before us of necessity belongs to the Congress").

80 Abrams v. United States, 250 U.S. 616, 630 (1919) (Holmes, J., dissenting).

81 Cohen v. California, 403 U.S. 15, 25 (1971).

82 Abrams, 250 U.S. at 630 (Holmes, J., dissenting). 
lation of all forms of ideas and images that get communicated between human beings. The Brandenburg paradigm's model of government posits an entity that is strong enough to advance the policy preferences of the political majority, but is also constrained by the requirement that neither the new majority's preferences nor the government that enforces them can be viewed as unassailable. Under such a system, all policy arrangements and political details will be considered impermanent, and all governments will come with an implicit expiration date.

Most importantly with regard to the application of the Brandenburg paradigm beyond political speech, neither a particular government policy nor the existence of the government itself nor the principles that the government enshrines can be considered sacrosanct. It says something significant about a government that the document constituting that government allows the government's flag to be burned $^{83}$ and allows citizens to refuse to pledge allegiance to that government. ${ }^{84}$ In many ways this is simply the codification of basic democratic theory: the government is constituted by the citizenry, whose members are existentially independent from the government. In the context of the First Amendment, these precepts have very specific consequences for all government regulation of speech undertaken to advance a particular governmental perspective on realityeven if that perspective cannot be characterized technically as "political."

In contrast to the Brandenburg paradigm's perspective on the government, the paradigm contains two complementary but somewhat different views of the model citizen, depending upon whether one emphasizes the optimistic or pessimistic underpinnings of the Brandenburg paradigm. The optimistic version of the Brandenburg paradigm's model of the citizen draws upon the observations in Brandeis's Whitney concurrence ${ }^{85}$ and posits a rational person capable of applying critical intelligence to the surrounding world without relying on the crutch of an intermediary institution such as the government to filter out dangerous or harmful information or ideas.

83 See United States v. Eichman, 496 U.S. 310, 318-19 (1990) (holding unconstitutional a federal statute criminalizing the burning of an American flag); Texas v. Johnson, 491 U.S. 397, 406-410, 420 (1989) (holding unconstitutional a state statute criminalizing the burning of an American flag).

84 See W. Va. State Bd. of Educ. v. Barnette, 319 U.S. 624, 642 (1943) (holding unconstitutional a state law requiring citizens to pledge allegiance to the flag).

85 See Whitney v. California, 274 U.S. 357, 375 (1927) (Brandeis, J., concurring) (describing free speech as the "means indispensable to the discovery and spread of political truth" among free citizens). 
This model citizen is informed and educated and fully capable of sorting out truth from falsehood, and therefore is unlikely to be duped by speakers seeking to lead citizens into illegal activity or other temptations.

In contrast, the pessimistic view of the model citizen under the Brandenburg paradigm is not as flattering toward that citizen. The pessimistic view assumes nothing about either the intelligence or the perspicacity of the model citizen. Thus, it is a view that takes citizens as they come-that is, as deeply flawed-and asserts the radically populist proposition that citizens have the right to adopt stupid or misguided ideas as their own. The pessimistic view makes no claims about speech improving the lives of the citizens, nor does it claim that free speech will necessarily educate or inform the populace. Rather, the pessimistic view takes to heart the agnosticism built into the First Amendment and uses that agnosticism to challenge the very idea that there should be a "model" citizen. Indeed, the very idea of a "model" citizen smacks of the kind of paternalism that the Brandenburg paradigm renounces. According to the pessimistic view of the citizen under the Brandenburg paradigm, citizens can think what they want and be who they want, regardless of whether their choices offend their neighbors or distress the government.

Whether one accepts the optimistic or pessimistic view of the model First Amendment citizen, the Brandenburg paradigm operates the same. Under both the optimistic and pessimistic views, the operative term for implementing the Brandenburg paradigm's scheme of constitutional speech regulation is "emergency." As explained in the previous Section, if there is no emergency-defined as a situation in which there is no time for counter-speech-there is no cause for government intervention in the speech market. Likewise, if an example of speech does not threaten an immediate, particularized, concrete harm, then that speech cannot be regulated at all. Beyond the mechanics of how the Brandenburg paradigm allows the government to regulate speech, however, the Brandenburg paradigm's views of both the government and the citizenry have broad implications for the basic objectives of government itself. Under the Brandenburg paradigm, government does not exist to provide moral or civic education to the citizenry; it does not exist to uplift its citizens spiritually (a point reinforced by the existence of the Establishment Clause within the First Amendment); and it is not there to protect them from thinking bad thoughts or reading bad books or watching bad movies. While the Brandenburg paradigm would recognize that the protection of health and the prevention of harm are legitimate government functions, the thrust of the paradigm would emphasize that in order to stay within 
its proper mandate, the government must focus on physical health and harms, not mental or spiritual ones.

\section{NONPOLITICAL SPEECH AND THE FLIGHT FROM BRANDENBURG}

Much of what has been said in the first portion of this Article is intended to establish the breadth and depth of the Brandenburg paradigm within the Supreme Court's First Amendment jurisprudence. This material is a prelude to a discussion of one of the central puzzles of First Amendment jurisprudence, which will be the focus of the remainder of this Article. The puzzle is this: Why, given the Court's continued allegiance to the comprehensively speech-protective theory of the First Amendment embodied in the Brandenburg paradigm, does the Court so often honor that theory in the breach by articulating far less speech-protective rules to govern areas of speech that do not fit into the narrow confines of the political advocacy category? As noted at the beginning of this Article, the Court has created a plethora of speech categories other than political advocacy. The Court has applied to those alternative speech categories distinctive sets of rules that give the government far more leeway to regulate speech than it has within the context of the political advocacy category governed by the Brandenburg paradigm. The question is, what aspects of the Brandenburg paradigm has the Court decided to relinquish in these alternative speech contexts and why?

Academic commentators have suggested various rationales for subdividing the First Amendment, which will be dealt with in the next Part. The Court itself seldom makes a serious effort to justify creating multiple different First Amendments, other than to toss out the occasional snide suggestion that "few of us would march our sons and daughters off to war to preserve the citizen's right to see 'Specified Sexual Activities' exhibited in the theaters of our choice." J6 Justice Stevens uttered this statement in his majority opinion in a case involving the zoning of theaters specializing in sexually explicit materials. ${ }^{87}$ The statement was part of his response to the claim that the regulation of this type of speech was no different than the regulation of political speech. Justice Stevens noted with approval the Court's frequent citation to Voltaire's defense of free speech, and “our zealous adherence to the principle that the government may not tell the citizen what he may or may not say." 88 He then goes on to say, however,

\footnotetext{
86 Young v. Am. Mini Theatres, Inc., 427 U.S. 50, 70 (1976).

$87 \quad I d$.

$88 \quad I d$. at 63.
} 
that "it is manifest that society's interest in protecting this type of expression is of a wholly different, and lesser, magnitude than the interest in untrammeled political debate that inspired Voltaire's immortal comment." ${ }^{" 99}$ Justice Stevens makes no attempt to justify these distinctions beyond repeating the ipse dixit that "every schoolchild can understand why" ${ }^{\prime 00}$ we must strongly protect political speech.

Courts that go beyond simply stating the obvious-that it is "manifest" that political speech receives more protection under the First Amendment than other types of speech-usually resort to some measure of the "seriousness" of speech. The more serious the speech, the more protection it receives under the First Amendment. One example of this phenomenon is a free speech case decided by Judge Richard Posner, involving the firing of a male policeman for having a casual conversation with a young woman while off duty. ${ }^{91}$ One of the ex-policeman's claims was that his conversation was protected by the First Amendment. ${ }^{92}$ Judge Posner disagreed. In justifying this result, Posner argued that the purpose of the First Amendment "is to protect the market in ideas, broadly understood as the public expression of ideas, narratives, concepts, imagery, opinionsscientific, political, or aesthetic - to an audience whom the speaker seeks to inform, edify, or entertain.. ${ }^{93}$ The First Amendment did not protect the ex-policeman in this case, Posner concluded, because "[c]asual chit-chat between two persons or otherwise confined to a small social group is unrelated, or largely so, to that marketplace." ${ }^{94}$ Posner goes on to argue that the First Amendment is primarily concerned with "the advancement of knowledge, the transformation of taste, political change, [and] cultural expression." ${ }^{95}$

This assessment of the difference between serious, high-value speech (which is highly protected by the Constitution) and trivial, low-value speech (which receives little or no constitutional protection) is consistent with many of the things that the Supreme Court has said over the years when dealing with the regulation of speech outside the political advocacy area. It hardly needs emphasizing that this is an exceedingly elitist notion of free speech. According to this theory, the First Amendment protects speech that appeals to indi-

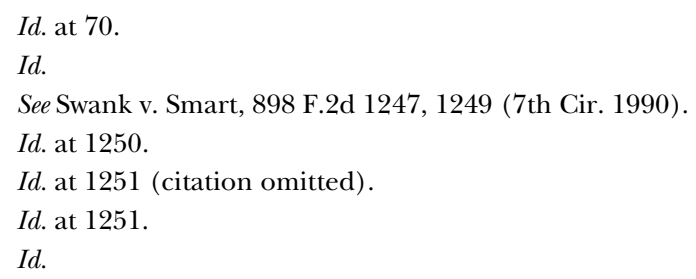


viduals who are highly educated, culturally sophisticated, or politically engaged, and does not protect the speech that everyday people engage in while living their daily lives.

Discussions of the high-value/low-value distinction sometimes combine the notion of seriousness with the perception of moral rectitude. In the Court's nude-dancing cases, for example, the Court allowed the government to prohibit total nudity among dancers whose express intention was to sexually arouse the audience, but did so using an analysis that would presumably forbid the government from applying the same total ban on nudity to those engaged in "serious" theatrical productions. ${ }^{96}$ In the Court's most recent decision upholding a government prohibition of nude dancing, the plurality adopted a "secondary-effects" analysis, noting that "the ordinance prohibiting public nudity is aimed at combating crime and other negative secondary effects caused by the presence of adult entertainment establishments." ${ }^{97}$ The Court adopted this analysis from Justice Souter's concurring opinion in the Court's previous nude-dancing case. In his discussion of the secondary-effects analysis in that case, Justice Souter noted that:

[T] he secondary effects rationale on which I rely here would be open to question if the State were to seek to enforce the statute by barring expressive nudity in classes of productions that could not readily be analogized to . . . adult films .... . It is difficult to see, for example, how the enforcement of Indiana's statute against nudity in a production of "Hair" or "Equus" somewhere other than an "adult" theater would further the State's interest in avoiding harmful secondary effects . . . 98

This analysis in effect creates two different types of expressive nudity. The first type is explicitly erotic and is performed in venues that are somewhat off the beaten track for the good, solid, suburban citizen. The second type cloaks its eroticism in the soothing particulars of the legitimate theater, which is usually performed in a space located in one of the nicer sections of town.

It is possible to view the dichotomy the Court draws between "good" eroticism and "bad" eroticism in several ways. One possibility is that the Court is distinguishing between the types of people who go to see the "bad" types of erotic dancing and those who go to legitimate theater with erotic elements, in much the same way that earlier

96 See City of Erie v. Pap's A.M., 529 U.S. 277, 296-302 (2000) (O'Connor, J., plurality opinion) (upholding the application of the city's public indecency ordinance to prohibit nude erotic dancing); Barnes v. Glen Theatre, Inc., 501 U.S. 560, 568-72 (1991) (upholding the application of Indiana's public indecency statute to expressive nudity).

97 Pap's A.M., 529 U.S. at 291.

98 Barnes, 501 U.S. at 585 n.2 (Souter, J., concurring). 
courts defined the general obscenity standard with the specific purpose of denying erotic materials to those who are especially susceptible to their influence-i.e., the lower classes. ${ }^{99}$ A second possibility is that the Court is simply distinguishing between different types of responses elicited by the expression in question. Under this alternative, if the expressive nudity is used in a context that generates serious thought and contemplation, then the speech is protected. Conversely, if the expressive nudity is used in a context that generates salacious feelings and immoral sexual urges, then the expression is not protected. Yet a third possibility is that the Court is really serious about its secondary effects explanation. Admittedly, it is difficult to take the secondary effects rationale seriously, given the breadth and background of most of the statutes involved in these cases and the way the Court has applied the secondary effects doctrine to the statutes. As for the statutes, the very fact that they ban nudity altogether instead of focusing on the effects that the statutes are purportedly designed to address suggests that the statutes really target the nudity rather than the criminal effects. As for the secondary effects doctrine, the fact that the Court does not require local governments to prove secondary effects before banning speech altogether ${ }^{100}$ suggests that the Court is not particularly concerned with criminal activity at all.

Any of these possibilities could explain the Court's action in the nude-dancing cases. What is significant, however, is that all of these explanations are inconsistent with various aspects of the Brandenburg paradigm. Distinguishing between the different audiences of "bad" nude dancing and "good" theatrical nudity, for example, is deeply inconsistent with the egalitarian underpinnings of the Brandenburg paradigm. Under the Brandenburg paradigm, the state has no role whatsoever in paternalistically deciding that some people are fit to hear or see particular expression while others are not. Under Brandenburg, the state is allowed to punish criminal behavior, but it is not allowed to identify those whom it thinks will become criminals.

As for the possibility that in permitting the regulation of nude dancing the Court was distinguishing between pure eroticism and the ity material whose tendency is to "deprave and corrupt those whose minds are open to such immoral influences, and into whose hands a publication of this sort may fall").

100 In the Court's secondary effects cases municipalities seeking to regulate speech on the basis of secondary effects have been allowed to rely on evidence that is merely "reasonably believed to be relevant" to the secondary effects issue. City of Renton v. Playtime Theaters, Inc., 475 U.S. 41, 51 (1986). The Court therefore does not require municipalities to produce definitive proof that specific speech will cause specific secondary effects. 
use of erotic symbols to advance a less sensuous and more rational intellectual project, this too is inconsistent with the basic elements of the Brandenburg paradigm. Under the Brandenburg paradigm, the government is not allowed to distinguish between good thoughts and bad thoughts, nor is it allowed to use its regulatory powers to favor thought that is socially useful versus thought that runs contrary to society's prevailing mores. Citizens may consider for themselves the value of all ideas and conceptions of the universe-no matter where those ideas lead and regardless of the form in which those ideas get packaged.

Finally, perhaps the most deeply flawed explanation for the Court's nude-dancing cases is the Court's suggestion that it is permitting cities to ban nude dancing because the dancing might attract antisocial or illegal activities. This explanation flies in the face of several different aspects of the Brandenburg paradigm. Since the Court does not require local governments to prove harm before regulating the speech, the Court's approach violates the Brandenburg harm principle. Likewise, since local governments are allowed to regulate in advance of any real problem, the Court's approach violates the Brandenburg immediacy requirement. By the same token, the Court violates another precept of Brandenburg by allowing local governments to take an extremely risk-averse attitude toward speech that powerful elements of the community do not like and which may attract criminal activity. Finally, by silencing the speaker in order to control potential listeners who may come to hear what the speaker has to say (or see the speaker's expression), the Court has violated one of the central components of the Brandenburg paradigm by shifting the responsibility for potential lawbreaking from the lawbreaker to the speaker.

What is one to make of the Court's willingness to virtually ignore several of the most important aspects of its own First Amendment jurisprudence in a case whose outcome depends entirely on the application of First Amendment principles? In the absence of a comprehensive explanation by the Court itself, it is left to outside observers to speculate about the nature of the conceptual differences between types of speech that drive members of the Court essentially to create a multitude of different First Amendments-one very protective First Amendment for political speech and advocacy, and a series of other, often far less protective First Amendments for a series of other types of speech. The question is whether one can make a plausible case for the existence of conceptual differences between the different types of speech identified by the Court, and if these conceptual differences do exist, whether they justify protecting speech within nonpolitical cate- 
gories much less rigorously than the Court is willing to protect speech advocating illegal activity or the violent overthrow of the government.

This question can best be addressed by looking at the First Amendment jurisprudence applicable to several specific categories of speech that the Court has created outside the advocacy of political speech area. The next four Sections undertake this task by looking at four specific categories of nonpolitical speech regulation. The first two categories involve so-called "teaching speech" and "true threats." These two categories are important because they are closely related to political speech and yet may not receive anything close to the level of protection granted traditional advocacy. The third category addressed below involves sexually explicit speech. As noted above in the discussion of the Court's nude-dancing cases, the Court has devised a series of jurisprudential mechanisms to avoid granting protection to this type of speech. This is true even though government regulation of sexually explicit speech raises the very question of collective moral regulation that lies at the heart of the Brandenburg paradigm mandate that the government regulation of speech must always remain content and viewpoint neutral. The fourth category of speech considered below involves student speech in public schools. Speech within this category raises the issue of whether particular circumstances justify the sort of government regulation that would be illegitimate in the broader world.

\section{A. "True Threats" and Intimidation: The Partitioning of Political Speech}

The category of speech labeled "true threats" is a bit of a puzzle. The category clearly exists, having been created by the Supreme Court nearly forty years ago as a constitutional gloss on the federal statute criminalizing threats against the President, ${ }^{101}$ but the Court has never defined the exact parameters of the "true threat." Instead, the Supreme Court has left to lower courts the task of filling in the details of the category, a task that lower courts have performed inconsistently and sometimes in virtually total disregard for the usual constitutional limits on government regulation of speech.

This is especially disturbing given the fact that many of the opinions raising the true threats issue involve speech of a political nature. Indeed, the case that created the true threats category itself involved political speech-an anti-Vietnam War speech in which the Court characterized the speaker as having engaged in "political hyperbole"

101 See Watts v. United States, 394 U.S. 705, 708 (1969) (per curiam) (establishing true threats as a distinct category in Supreme Court jurisprudence). 
against the President rather than a "true threat." ${ }^{102}$ The Court went out of its way to emphasize that speech in the political arena is "often vituperative, abusive, and inexact." ${ }^{103}$ The Court would make a similar point over a decade later in Claiborne Hardware when it would extend the protection of Brandenburg to a speaker using aggressively threatening language in a context where actions similar to those threatened had already been carried out. ${ }^{104}$ The Court effectively subsumed threats into the general range of vociferous political discourse. Threats such as promises to "discipline" those who violated an economic boycott ${ }^{105}$ were transformed by the Court into "emotionally charged rhetoric," "impassioned plea[s]," "strong language," and "spontaneous and emotional appeals for unity and action in a common cause." 106 In other words, even speech that overtly takes the form of a threat is not a constitutionally unprotected "true threat" so long as the atmosphere in which the threat is uttered is such that it is merely a part of aggressive political discourse.

If Watts and Claiborne Hardware were the only decisions dealing with the concept of the true threat, then we would still be unclear what a true threat is, but at least we would have some assurance that the concept of a true threat could not be enforced in a way that would limit political discourse. Unfortunately, these two cases are not the only word on the subject. The Court has also addressed the concept of the true threat in a political context on one other occasion, in a decision that confuses much more than it clarifies. In Virginia $v$. Black, ${ }^{107}$ the Supreme Court upheld a Virginia statute making it a crime to burn a cross in any public place with the intent of intimidating any person or group. The case involved three defendants. Two of the defendants had been convicted under the Virginia statute for burning a cross on the lawn of a next-door neighbor. ${ }^{108}$ The third defendant had been convicted under the Virginia statute for burning a cross as part of a Ku Klux Klan rally, which was held in a private field and attended only by Klan followers. ${ }^{109}$

\footnotetext{
$102 I d$.

103 Id.

104 See NAACP v. Claiborne Hardware Co., 458 U.S. 886 (1982) (overturning on Brandenburg grounds a civil damages award against the NAACP and its leaders that was based on speeches threatening local residents to honor an NAACP boycott of white businesses). 
Justice O'Connor's opinion for the Court's majority in Virginia $v$. Black is both confused and confusing. In many ways, Justice O'Connor wrote two separate opinions. One of these opinions suggests that there is an entirely separate category of First Amendment jurisprudence involving "intimidating" speech. To bolster this position, O'Connor begins her opinion in Black with a long description of the history of the violent activities of the $\mathrm{Ku}$ Klux Klan, noting that "the Klan used cross burnings as a tool of intimidation and a threat of impending violence." ${ }^{110}$ This history suggests that burning crosses communicate a distinctive message that makes them especially susceptible to government regulation, which Justice O'Connor confirms later in the opinion. "The First Amendment permits Virginia to outlaw cross burnings done with the intent to intimidate because burning a cross is a particularly virulent form of intimidation." 111 Thus, in this part of Justice O'Connor's Black opinion, it seems that she is embracing the notion that states can outlaw particular political symbols if those political symbols have a violent history, or (to put the matter in the worst First Amendment light) if the symbols are associated with highly unpopular political groups and are especially effective at communicating the views of those groups. Needless to say, this proposition directly treads on Brandenburg's turf and seems to violate virtually every one of the elements of the Brandenburg paradigm.

The disconcerting implication that in Black the Court intended to revisit certain parts of Brandenburg is ameliorated to some extent by the other half of Justice O'Connor's schizophrenic Black opinion. Having gone to great lengths in the first part of her opinion to establish that cross-burning is an especially intimidating symbol that is worthy of state regulation for that very reason, Justice O'Connor then turns to the second part of her opinion in which she takes away from the state much of the authority she has just granted. In the second part of Justice O'Connor's Black opinion, she treats intimidating speech as merely a subset of the true threat. "Intimidation in the constitutionally proscribable sense of the word is a type of true threat, where a speaker directs a threat to a person or group of persons with the intent of placing the victim in fear of bodily harm or death." ${ }^{112}$ She then goes on to hold unconstitutional the provision of the Virginia cross-burning statute that made burning a cross prima facie evidence of an intent to intimidate. ${ }^{113}$ As a result, the Court overturned

\footnotetext{
$110 \quad I d$. at 354.

111 Id. at 363.

$112 I d$. at 360.

113 Id. at 363-67.
} 
the conviction of the third defendant in Black on the ground that his speech was entirely political and therefore could not legitimately be construed as intimidation or a true threat. The other two defendants' cases were remanded for reconsideration by the state courts under the Virginia statute denuded of the prima facie evidence provision.

There are many problems with Justice O'Connor's opinion in Black. These problems stem from the internal contradictions in the opinion. On one hand, Justice O'Connor approves of the state singling out cross burning as an especially intimidating form of speech. On the other hand, at other points in the opinion, Justice O'Connor chides the state for subjecting to criminal punishment someone who is using the burning cross as nothing more than "a statement of ideology, a symbol of group solidarity."114 Having said that, however, Justice O'Connor then permits the state to single out threats using burning crosses for greater punishment than threats in general. "Instead of prohibiting all intimidating messages, Virginia may choose to regulate this subset of intimidating messages in light of cross burning's long and pernicious history as a signal of impending violence." "But if this is true, then why, given the Court's own recognition of "cross burning's long and pernicious history as a signal of impending violence," 116 does O'Connor turn around and prohibit the state from prosecuting any and all evidence of cross-burning? After all, in light of the Court's own historical discussion, the burning cross seems to have little message beyond "signal[ing] impending violence," which is hardly the stuff of ordinary political discourse.

Aside from these contradictions, perhaps the biggest problem with the Court's opinion in Black is that it once again demonstrates the Court's unwillingness to define the parameters of the true threat category of speech. Because of this unwillingness, the category of true threats has been defined largely by lower-court opinions. Unfortunately, these opinions go in a range of different directions, from providing almost Brandenburg-style protection of threatening speech to providing virtually no protection at all. Indeed, the two most prominent true threats decisions in the lower courts operate at opposite ends of the free speech continuum-the Second Circuit's opinion in United States v. Kelner ${ }^{117}$ at the protective end of the continuum, and the Ninth Circuit's opinion in Planned Parenthood of the Colum-

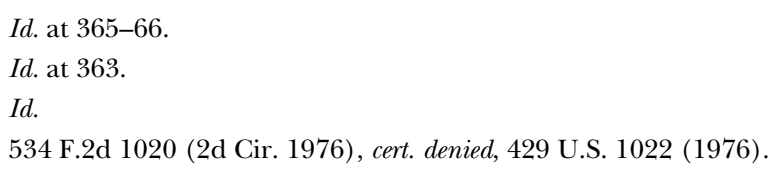


bia/Willamette, Inc. v. American Coalition of Life Activists ${ }^{118}$ at the opposite, unprotective end of the continuum.

Kelner is one of the most frequently cited true threats opinions. The case involved statements made by members of the Jewish Defense League (the JDL) against Yasser Arafat of the Palestine Liberation Organization (the PLO), on the occasion of Arafat's visit to New York to address the United Nations General Assembly. ${ }^{119}$ During a televised news conference, Kelner, a member of the JDL, explicitly threatened to kill Arafat and purported to have the killing planned "in detail." ${ }^{120}$ Kelner was convicted under the federal threats statute and, on appeal, argued that this conviction was improper because he was merely engaged in political speech intended to show that Jews would defend themselves against PLO threats. ${ }^{121}$ The Second Circuit rejected his appeal, but only after articulating a very narrow definition of true threats: "So long as the threat on its face and in the circumstances in which it is made is so unequivocal, unconditional, immediate and specific as to the person threatened, as to convey a gravity of purpose and imminent prospect of execution, the [threats] statute may properly be applied." ${ }^{122}$ The protective parts of this standard are the explicitness and imminence requirements. A conviction based on evidence falling short of what Kelner provided the prosecutors in this case-i.e., explicit statements of his intention to maim or kill, and effectively naming the date on which the action would take place-would fail to satisfy the First Amendment. Ambiguous or hypothetical threatening statements simply would not pass muster under this standard.

In contrast to Kelner, the Ninth Circuit's opinion in Planned Parenthood seems to be from a different First Amendment universe. ${ }^{123}$ Like Kelner, Planned Parenthood involved aggressive political speech. Specifically, Planned Parenthood involved a website and posters that attacked clinic workers, doctors, and others that participated in or facilitated abortions. ${ }^{124}$ The website and posters identified various individuals as guilty of crimes against humanity and subject to a hypothetical future Nuremberg-style trial. ${ }^{125}$ Four doctors and several

290 F.3d 1058 (9th Cir. 2002) (en banc), cert. denied, 539 U.S. 958 (2003).

Kelner, 534 F.2d at 1020-21.

Id. at 1021.

Id. at 1021-22.

Id. at 1027.

Planned Parenthood of the Columbia/Willamette, Inc. v. Am. Coal. of Life Activists, 422 F.3d 949 (9th Cir. 2005), cert. denied, 547 U.S. 1111 (2006).

$124 I d$.

125 Id. at 952. 
clinics and abortion-rights organizations brought suit against those who devised the website and posters under the federal Freedom of Access to Clinic Entrances Act, which permits civil suits against anyone who by "threat of force ... intentionally ... intimidates" someone seeking reproductive health services. ${ }^{126}$ The case was tried before a jury in federal court, and the jury awarded the plaintiffs millions of dollars in damages, including a total of $\$ 108.5$ million in punitive damages (which were reduced on appeal on due process grounds). ${ }^{127}$

On appeal, the Ninth Circuit rejected the defendants' argument that the case should be considered under traditional political speech protections and decided instead to treat the claim as falling within the court's true threats jurisprudence. Accordingly, the Ninth Circuit applied the following "objective" standard for what can be considered a true threat: "whether a reasonable person would foresee that the statement would be interpreted by those to whom the maker communicates the statement as a serious expression of intent to harm or assault." ${ }^{128}$ Utilizing this standard, the Ninth Circuit upheld the jury verdict in Planned Parenthood. This standard is virtually the polar opposite of the standard used by the Second Circuit in Kelner and is so lenient as to practically remove the First Amendment from consideration in true threats cases. As a measure of how lenient the standard is, consider that the Ninth Circuit's "objective" true threat standard incorporates none of the three elements of Brandenburg. The standard lacks any reference to immediacy, so speech can be treated as a true threat without regard to whether the threat will be carried out at any point in the near future. The standard also does not require the threat to be explicit, as evidenced by the fact it was applied to uphold a threats verdict in a case in which none of the speech in question contained any explicit threats. And finally, the Ninth Circuit renounced any requirement that the speaker intended to threaten the victim: "It is not necessary that the defendant intend to, or be able to carry out his threat; the only intent requirement for a true threat is that the defendant intentionally or knowingly communicate the threat." 129

12618 U.S.C. $\$ 248$ (a) (1) (2006) (providing for civil suits against those who discourage these reproductive services through threats or intimidation).

127 Planned Parenthood, 422 F.3d at 949.

128 Planned Parenthood of the Columbia/Willamette, Inc. v. Am. Coal. of Life Activists, 290 F.3d 1058, 1074 (9th Cir. 2002) (quoting United States v. Orozco-Santillan, 903 F.2d 1262, 1265 (9th Cir. 1990)) (setting forth one standard for assessing true threats).

129 Id. at 1075 . Note that some subsequent Ninth Circuit panels considering this issue have ruled that under the United States Supreme Court's opinion in Black, "We are . . bound to conclude that speech may be deemed unprotected by the First Amendment as a 'true 
A broad definition of the true threats category may greatly circumscribe the protection of political speech. Note that with the exception of the first two defendants in Black, all of the speech involved in the true threats cases discussed thus far has been overtly political in nature. Also recall that in two of the three foundational cases in the political speech area-Brandenburg and Claiborne Hardware-the speech that the Court characterizes as political was in fact overtly threatening in nature. ${ }^{130}$ So discussions of the standards applicable to true threats are important because those standards will frequently bleed over into the area of political speech.

Given the close association of political speech and true threats, what does the Brandenburg paradigm tell us about the proper standard that should be applied in the true threats area? Many of the Brandenburg paradigm components can be applied directly to the problems raised by true threats. It is easy and uncontroversial, for example, to apply the ideological agnosticism component of the Brandenburg paradigm to true threats, in the sense that all of the true threats precedents are consistent with the proposition that the government is not permitted to treat speech as a true threat simply because that speech takes an antagonistic or controversial side of a public debate. Applying the immediacy component of the Brandenburg paradigm is equally easy but perhaps more controversial. The immediacy requirement is what separates the Kelner standard from the Ninth Circuit approach in Planned Parenthood. In Planned Parenthood, the court simply takes a reasonable person approach to identifying true threats, leaving it to the jury to determine whether a distant threat is sufficiently fearsome to warrant legal sanction. Under the Kelner standard, on the other hand, a criminal threats prosecution can only be based on proof beyond a reasonable doubt of an imminent threat.

threat' only upon proof that the speaker subjectively intended the speech as a threat." United States v. Cassel, 408 F.3d 622, 633 (9th Cir. 2005). The full Ninth Circuit has not yet resolved the issue of whether to use a Planned Parenthood-style objective standard or a Cassel-style subjective standard for determining the existence of true threats. See Fogel v. Collins, 531 F.3d 824, 831 (9th Cir. 2008) ("This circuit has thus far avoided deciding whether to use an objective or subjective standard in determining whether there has been a 'true threat."').

130 See NAACP v. Claiborne Hardware Co., 458 U.S. 886, 902 (1982) (during a public speech to support an economic boycott of local businesses, speaker asserts that "If we catch any of you going in any of them racist stores, we're gonna break your damn neck"); Brandenburg v. Ohio, 395 U.S. 444, 446 (1969) (speaker threatens to take "some revengeance" against various people and institutions if they continued to "suppress the white, Caucasian race"). 
Courts that would disagree with the introduction of an immediacy requirement for true threats prosecutions are in essence making a value judgment about the First Amendment value of speech containing threatening language. This is where the clash between existing true threats jurisprudence and the Brandenburg paradigm becomes most evident. Phrasing this dispute in terms of the components of the Brandenburg paradigm, this clash probably pertains to disagreements over the importance of four different Brandenburg factors: the harm principle, the assumption of high collective risk tolerance, the shifting of legal liability from speaker to actor, and the assumption of listener incredulity. Courts that adopt very lenient standards for prosecuting true threats implicitly make a series of assumptions that are quite different than those made by the Supreme Court in Brandenburg and its companion cases.

Courts that apply a lenient standard to true threats stray from the usual Brandenburg requirement that the harm created by proscribed speech must be concrete. In the usual Brandenburg case, feelings of unease and even trauma are insufficient to justify legal regulation of the renegade speech. ${ }^{131}$ In the true threats cases, on the other hand, protecting the victim from feelings of unease and trauma are precisely the object of the legal exercise. None of the true threats cases require evidence that the victim of the threat actually changed his or her behavior as a result of the threatening speech. The cases simply require that the perception of a threat be reasonable (in the Ninth Circuit's rendition of the standard) ${ }^{132}$ or (in the more speech-friendly Second Circuit rendition of the standard) that the threat be unconditional and specific enough to justify the conclusion that it may be carried out. ${ }^{133}$ Although the Second Circuit standard comes close to requiring a Brandenburg-style concrete harm before sanctioning the speech, the Ninth Circuit standard simply leaves the matter up to the jury-even when the speech in question is highly political in ways that

See Terminiello v. Chicago, 337 U.S. 1, 4 (1949) ("Accordingly a function of free speech under our system of government is to invite dispute. It may indeed best serve its high purpose when it induces a condition of unrest, creates dissatisfaction with conditions as they are, or even stirs people to anger. Speech is often provocative and challenging. It may strike at prejudices and preconceptions and have profound unsettling effects as it presses for acceptance of an idea. That is why freedom of speech, though not absolute, is nevertheless protected against censorship or punishment, unless shown likely to produce a clear and present danger of a serious substantive evil that rises far above public inconvenience, annoyance, or unrest." (citations omitted)).

132 See Planned Parenthood, 290 F.3d at 1074 (quoting United States v. Orozco-Santillan, 903 F.3d 1262, 1265 (9th Cir. 1990)) (describing the reasonableness standard).

133 See United States v. Kelner, 534 F.2d 1020, 1027 (2d Cir. 1976) (describing the Second Circuit's immediacy analysis for true threats). 
are indistinguishable from the speech in cases such as Claiborne Hardware.

Along the same lines, a lenient true threat standard such as the one adopted by the Ninth Circuit abandons the Brandenburg paradigm's assumptions about a high collective tolerance of expressive risks. The Ninth Circuit treats threatening speech as indistinguishable from every other tortious or criminal activity, inviting the sort of risk-averse balancing between harms and benefits that accompany legal regulation of every other kind of human activity. Under such a system, speech would not be given the favorable treatment over other human activities that it is currently afforded under the Brandenburg paradigm.

The explanation for the abandonment of the Brandenburg paradigm's mandate of high risk tolerance in true threats cases is the simultaneous refusal of courts such as the Ninth Circuit to maintain either the Brandenburg paradigm's shift of legal liability from speaker to actor, or the complementary assumption of listener incredulity. In the Ninth Circuit's Planned Parenthood decision, there is no indication anywhere in the record that individuals or groups accused of true threats were themselves intending to carry out the threats. ${ }^{134}$ Instead, the Ninth Circuit permitted liability to attach on the theory that the defendants' speech might instigate other unnamed individuals to engage in violent action against the plaintiffs. If this case were litigated as an incitement case, therefore, the speaker would be completely insulated from legal liability, as in Claiborne Hardware. Likewise, if the Brandenburg paradigm's assumption of the listener incredulity prevailed, plaintiffs could not rely on the suggestion that someone might be moved by the defendants' speech to harm the plaintiffs. Any such suggestion could be rebutted by the Brandenburg paradigm's assumption that listeners have enough common sense to realize that a "Wanted" poster linked to some hypothetical future Nuremberg trial of abortion doctors is nothing more than political speech-emotional and incendiary political speech perhaps, but political speech nonetheless.

Cases such as Planned Parenthood illustrate the dangers of the Court's tendency to create one category of highly protected political speech, governed by the Brandenburg paradigm, and then a whole series of alternative categories in which the Brandenburg paradigm ap-

134 See Planned Parenthood, 290 F.3d at 1075 ("It is not necessary that the defendant intend to, or be able to carry out his threat; the only intent requirement for a true threat is that the defendant intentionally or knowingly communicate the threat."). 
plies very little if at all. The danger is not simply that in such a system nonpolitical speech will receive far less protection than political speech. The more insidious danger is that the lines between the different categories of speech are so amorphous that courts that wish to do so can easily shift some examples of political speech into the lesser-protected categories and thereby avoid the Brandenburg paradigm altogether. In fact, this is exactly what happened in Planned Parenthood. Despite the court's protestations to the contrary, ${ }^{135}$ there is little to distinguish the speech that was deemed unprotected in Planned Parenthood from the speech that the Supreme Court unanimously protected in Claiborne Hardware. Both cases involved speeches containing overtly threatening language, antagonists in emotional and sometimes violent political disputes, and contexts in which other antagonists in the disputes had already engaged in violence. Different legal results were possible in the two cases simply because the speech in one case was placed in the true threats category and the speech in the other case was placed in the advocacy category.

It makes little sense to allow litigants and courts to manipulate the legal result in free speech cases simply by maneuvering the speech in question into a different category, but this is an inevitable consequence of creating different standards for closely related types of speech. The real problem is not the existence of the categories themselves, but rather the fact that outside the category of political advocacy the courts tend to be very reluctant to apply the various components of the Brandenburg paradigm. This reluctance stems from the general perception that categories of speech other than political advocacy involve completely different issues than those raised by radical political speech. A close reading of the true threats cases casts doubt upon this perception, however.

It is relatively simple to apply most of the components of the Brandenburg paradigm to threats. As Kelner demonstrates, the agnosticism, harm principle, and immediacy components of the Brandenburg paradigm can be integrated into a true threats standard without in any way diminishing the government's ability to address real threats to persons or property. Once these components are incorporated into the true threats analysis, the collective risk tolerance and listener incredulity assumptions of the Brandenburg paradigm follow naturally. The fact is that in its Planned Parenthood decision, the Ninth Circuit never satisfactorily explains why the targets of the speech in

135 See id. 290 at 1073-74 (attempting to distinguish Claiborne Hardware from Planned Parenthood). 
that case should have been more frightened of the threatening speech directed at them than the targets of the equally threatening speech in Claiborne Hardware. It could be argued that the speech in Claiborne Hardware deserves even less protection than the speech in Planned Parenthood. The speech in Claiborne Hardware took place in a small town, where virtually everyone in town was involved in the dispute, where violence similar to that promised in the threatening speech had occurred in the immediate past, and where those associated with the speaker had been directly engaged in the violence. ${ }^{136}$ The speech in Planned Parenthood, on the other hand, took place in a much more general context (such as the World Wide Web), there was no indication that the speakers carried out any of the violence or associated with anyone who did, and the speech was much less explicit than in Claiborne Hardware. In short, if the holding of Claiborne Hardware is right, then the holding of Planned Parenthood is wrong. Planned Parenthood misses the central theme of Claiborne Hardware and the other cases forming the heart of the Brandenburg paradigm: in general, legal liability for violence should be ascribed to the person perpetrating violence, not the person who suggests that violence might be a good thing.

None of this is intended to suggest that the application of the Brandenburg paradigm to true threats would fail to take into account the specialized circumstances that arise in some threatening situations. For example, in cases involving threats spoken publicly (such as both Kelner and Planned Parenthood) it makes sense to implement the Brandenburg paradigm in true threats cases by applying something very close to the standard used in Brandenburg itself-that is, by requiring evidence of an explicit threat, proof of the speaker's intent that the threat is going to be carried out, and some indication of the speaker's (in Kelner's phrasing) "gravity of purpose and imminent prospect of execut[ing the threat]." ${ }^{137}$ With regard to threats communicated privately, however, it would not be inconsistent with the Brandenburg paradigm to take into account the changed circumstances by altering the legal standard somewhat. It would not be inconsistent, for example, to drop the explicitness requirement with regard to privately communicated threats. When received personally and privately, a subtle reference can be far more disconcerting than a similar reference made in general at a public demonstration. A tele-

136 See NAACP v. Claiborne Hardware Co., 458 U.S. 886, 898-906 (1982) (reviewing the seven-year history of the dispute between the NAACP and local businesses). 
phone call made to an individual at home in the middle of the night in which the caller says "I know where you live" is far more ominous than a similar reference made in Claiborne Hardware to a general audience that the sheriff could not sleep with boycott violators at night. ${ }^{138}$

The point here is that the case for the Brandenburg paradigm does not require that the precise ingredients of the Brandenburg standard must be applied in every alternative category of speech. The key is that the same general assumptions about governmental power and personal responsibility that are made when considering legal regulation of political advocacy should be integrated into whatever legal standard applies to speech other than advocacy.

\section{B. The Regulation of "Teaching Speech"}

Two recent decisions raise the possibility that the courts may create within First Amendment jurisprudence a category of so-called "teaching speech"-that is, speech that conveys information or teaches about how to carry out illegal activity, rather than advocating that activity. Like "true threats," the teaching speech category is closely related to political advocacy, but there are suggestions in the case law that the category should be governed by a standard that would undermine much of the protection for speech offered by the Brandenburg paradigm. Today there is no opinion by the full $\mathrm{Su}$ preme Court discussing the proper standard that should be applied to teaching speech. Instead, we have two prominent lower court opinions that resolved the First Amendment issues related to teaching speech in diametrically opposed ways; one court would apply Brandenburg directly to teaching speech cases while the other would apply a standard that falls far short of Brandenburg. As with the category of true threats, the question is whether there is something in the nature of the teaching speech category itself that explains why the components of the Brandenburg paradigm should not apply to instructional or teaching speech.

The two decisions that have directly addressed the issue of teaching speech provide polar opposite readings of the relevant First Amendment concerns. In its decision in Rice v. Paladin Enterprises, Inc., ${ }^{139}$ the Fourth Circuit provides a very narrow approach to the

138 tors would be 'disciplined' by their own people and warned that the Sheriff could not sleep with boycott violators at night.")

139

128 F.3d 233 (4th Cir. 1997), cert. denied, 523 U.S. 1074 (1998). 
question whether the First Amendment protects speech of this sort. The case involved the book Hit Man: A Technical Manual for Independent Contractors. ${ }^{140}$ The book purported to be a primer on how to be an assassin. The book contained some fairly obvious information, such as the need to wear black when conducting a hit at night, the desirability of renting a car instead of driving one's own to a hit, and the advisability of using fake information when checking into a hotel during an assignment. ${ }^{141}$ The book also contains some odd suggestions, such as that a hit man might want to dispose of a body by cutting off the head, placing a stick of dynamite in the victim's mouth and "blow[ing] the telltale dentition to smithereens." "142

Many of the idiosyncrasies of the book can be explained by its genesis. Although the author's name is listed as "Rex Feral" (Latin for "king of the beasts"), the real author is a divorced mother of two who had originally written the book as a novel, but was urged by the publisher to turn it into a "how-to" manual. ${ }^{143}$ According to a Washington Post interview with the author, she obtained most of her information on how to be a hit man "from books, television, movies, newspapers, police officers, [her] karate instructor, and a good friend who is an attorney." 144

Despite the amateurish and at times absurd nature of the information in the book, the book was found in the possession of a real hit man named James Perry. ${ }^{145}$ Perry was hired by a man to kill his exwife, son, and the son's nurse, in order for the man to inherit the son's \$2 million settlement for injuries he had received in an accident. ${ }^{146}$ The victim's family sued the book's publisher, Paladin Press, for wrongful death under Virginia state law. ${ }^{147}$ The Fourth Circuit's decision in Rice is the appellate court's reversal of the district court's grant of summary judgment for the publisher on First Amendment grounds.

There are many strange aspects to both the appeal and the Fourth Circuit's decision, two of which are worth noting here. First of all, although the Fourth Circuit goes to great lengths to criticize the dangerous information contained in Hit Man, the Court also republishes

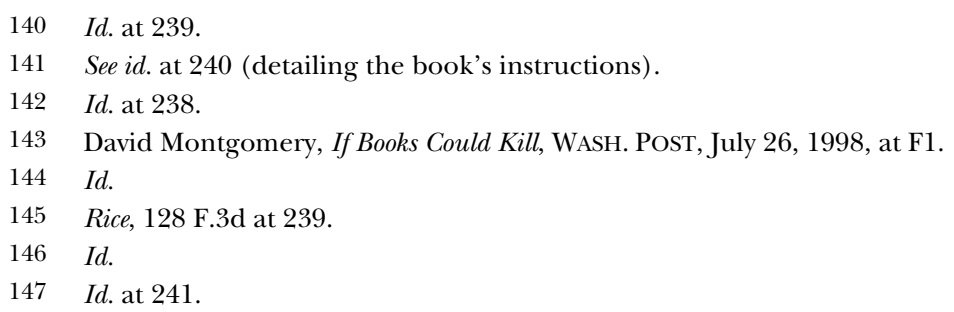


large portions of this information in its opinion, ${ }^{148}$ which is freely available on the Fourth Circuit website. ${ }^{149}$ Second, although Paladin Press defended on First Amendment grounds, it also stipulated to all three components of the Brandenburg standard. ${ }^{150}$ Rice should, therefore, have been an easy (and short) First Amendment decision. Even applying the most protective version of the First Amendment-that is, the Brandenburg standard-the speaker would lose because the speaker itself conceded that it had violated that standard.

Instead of publishing a concise opinion making this point, however, the Fourth Circuit instead submitted a long and meandering opinion detailing why the Brandenburg standard does not apply to instances of teaching or instructional speech. The court concluded that the speech in this case constituted criminal aiding and abetting ${ }^{151}$ and treated the speech as "tantamount to legitimately proscribable nonexpressive conduct." ${ }^{152}$ To reach this result, the court first asserts that teaching speech such as the information in the Hit Man is integral to the ultimate criminal act. ${ }^{153}$ The court then finely parses the language in Brandenburg itself, which seems to contradict the Fourth Circuit's holding in Rice. ${ }^{154}$ The court's basic conclusion regarding the first point is that the First Amendment does not protect speech that uses instructional language, especially when accompanied by language encouraging crime. ${ }^{155}$ The court's conclusion regarding the second point is that the protections offered by Brandenburg do not extend to "mere teaching," but rather to "mere abstract teaching"-a distinction that touches not only the teaching speech category, but also has potential ramifications for any speech that is cast in the form of action words rather than cloudy abstractions. In any event, by the end of the Fourth Circuit's discussion, very little is left of First Amendment protection of speech that communicates information or instructions that might be used by a reader or listener to commit a crime at some point in the indefinite future.

\footnotetext{
148 See id. at 235-41.

149 See id.

$150 \quad I d$. at $241-42$ n.2.

151 Id. at $242-43$.

152 Id. at 243.

153 Id. at 243-44 (discussing the concept of aiding and abetting as it relates to the regulation of free speech, and arguing that speech is not protected when it becomes an integral part of the ultimate criminal act).

154 Id. at 248-50, 263-65 (assessing the application of Brandenburg to teaching speech).

$155 I d$. at 248 ("[The First Amendment] would not relieve from liability those who would, for profit or other motive, intentionally assist and encourage crime and then shamelessly seek refuge in the sanctuary of the First Amendment.").
} 
A very different approach to these issues can be seen in the Ninth Circuit's opinion in McCoy $v$. Stewart. ${ }^{156}$ In some ways this case involved much more troubling speech than in Rice. Rice involved the general dissemination of a book containing non-specialized information that could have been obtained (and in fact was obtained by the author of the book) from a number of other common sources. $M c C o y$, on the other hand, involved the communication of specialized knowledge directly to individuals willing and able to use that information to do illegal things. The case involved speech that occurred at a party attended by gang members from Arizona and California. ${ }^{157}$ During the cookout, the Arizona gang members had a conversation with their compatriot from California about how California gangs conducted certain gang activities. ${ }^{158}$ The California gang member provided detailed advice about things such as initiation rites, gang ejection rituals, ${ }^{159}$ and "tagging" activities. ${ }^{160}$ Based on these conversations, the California gang member was indicted and ultimately convicted under an Arizona statute prohibiting the participation in a criminal street gang by "[f] urnishing advice or direction in the conduct" of the criminal enterprise. ${ }^{161}$

On an appeal of the defendant's federal habeas corpus proceeding, the Ninth Circuit Court of Appeals overturned the conviction on Brandenburg grounds using a straightforward application of Brandenburg, Hess, and Claiborne Hardware. ${ }^{162}$ The court treated the conversations as indistinguishable from any other incendiary speech that had no immediate effect on its listeners. ${ }^{163}$

The key to the Ninth Circuit's decision was the absence of immediate concrete consequences stemming from the speech. The court noted that the fact that the speech occurred at a barbecue and a party "made it unlikely anyone would act on [the speech] imminently."$$
61
$$

See ARIZ. Rev. StAT. AnN. § 13-2308(A) (3) (2009) ("A person commits participating in a criminal syndicate by:... Furnishing advice or direction in the conduct, financing or management of a criminal syndicate's affairs with the intent to promote or further the criminal objectives of a criminal syndicate"); see also McCoy, 282 F.3d at 628 (describing McCoy's indictment and conviction).

282 F.3d 626 (9th Cir. 2002), cert. denied, 537 U.S. 993 (2002).

Id. at 628 .

Id. at 630 .

Id. at $630 \mathrm{n} .4$

See id. (describing the underlying conviction and the facts that led to it and explaining gang practices of "jumping people in" and "jumping people out").

McCoy, 282 F.3d at 631-33.

Id. at 631 ("If anything, McCoy contends, his speech was advocacy of lawlessness at some indefinite future time. ... The record bears out his assertions.").

Id. at $631-32$. 
The court also noted that the California gang member's "advice was very general" in the sense that his ideas "were not aimed at any particular person or any particular time." ${ }^{165}$ Likewise, his advice about tagging "was given without any recommendation as to how or when to place the graffiti." 166 Throughout its discussion, the Ninth Circuit considered it irrelevant that the speech being prosecuted contained information and advice rather than language advocating action. Under Brandenburg, the Ninth Circuit suggests, the content of the speech does not determine the scope of the government's authority to silence that speech. ${ }^{167}$ In cases involving information as well as cases involving straight advocacy, the speech must be specific, the speech must create an immediate danger of illegal action, and the speech must be accompanied by evidence that the speaker intended that the illegal action occur. ${ }^{168}$

Other than providing a nice First Amendment counterpoint to the Fourth Circuit decision in Rice, the Ninth Circuit decision in McCoy might stand as little more than a routine application of Brandenburg were it not for an opinion the case generated in the United States Supreme Court. The Supreme Court denied certiorari in McCoy, but Justice Stevens submitted an opinion of his own in conjunction with the denial. ${ }^{169}$ Although Justice Stevens is careful not to express a point of view on the ultimate outcome of the issue, he seems essentially to embrace the same point of view that the Fourth Circuit took in Rice-i.e., that Brandenburg (and specifically the imminent harm component of the Brandenburg standard) does not apply at all to "speech that performs a teaching function." 170 According to Justice Stevens, expressive activities such as "oral advice, training exercises, and perhaps the preparation of written materials" in conjunction with criminal enterprises, "may create significant public danger" and therefore may not be covered by the First Amendment rights granted to political advocacy under Brandenburg. ${ }^{171}$

From a free speech perspective, it is disconcerting that a Justice often considered friendly to First Amendment concerns (and in fact who actually wrote the majority opinion in Claiborne Hardware) now suggests that Brandenburg does not apply at all to speech communicat-

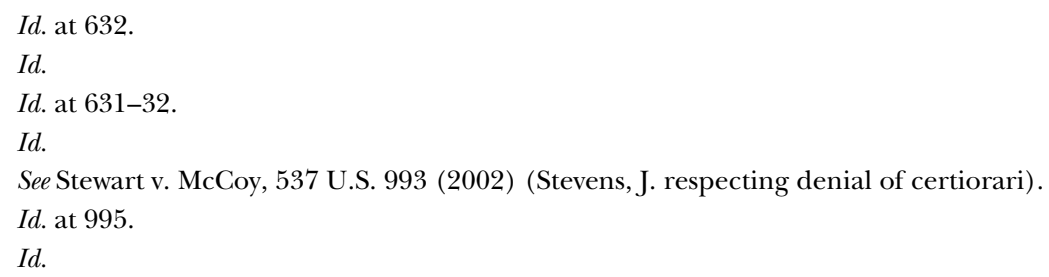


ing information. It is worth considering, therefore, whether it is plausible for courts such as the Fourth Circuit, and potentially even Justice Stevens, to arrive at this conclusion.

The best way to address this issue is to step back from the narrow focus on the three-part Brandenburg standard-requiring proof of incitement, imminent danger, and intent-and instead approach Brandenburg through the prism of the broader concerns that underlie the Court's political speech jurisprudence-that is, the concerns that comprise what I have termed the Brandenburg paradigm. After undertaking this analysis it becomes clear that the Ninth Circuit's holding in Rice and Justice Steven's suggestions about Brandenburg and teaching speech in $M c$ Coy are incompatible with these broader free speech concerns. As in the case of true threats, it is easiest to see the conflict between the Brandenburg paradigm and lenient free speech standards proposed in cases such as Rice by focusing on the applicability to teaching speech of two central features of the Brandenburg paradigm: first, the paradigm's requirement that the government prove concrete and immediate harm before censoring speech, and second, the paradigm's emphasis on listener responsibility and the complementary requirement that perpetrators of bad acts, rather than the speakers urging those acts, be held liable for harms resulting from speech.

The lenient standard proposed for teaching speech in Rice fails to meet the Brandenburg paradigm's requirement that courts identify an immediate, concrete harm before attaching legal liability to the expressive activities of a speaker. In the universe defined by the Rice standard, the publication of information that leads to the commission of an illegal act by an unrelated person several months or years later would render the publisher and author of the original publication liable for the ultimate act-even if the publisher and author did not know anything about the illegal act, did not encourage the illegal act, and did not intend that anyone use their expressive materials for an illicit purpose. ${ }^{172}$

The Fourth Circuit seems to suggest that the First Amendment would still protect the publication of some information-in the court's terms, information communicated in the form of "entirely in-

172 Although the defendant in Rice stipulated to the intent, clear and present danger, and incitement parts of the Brandenburg standard, see Rice v. Paladin Enters., Inc., 128 F.3d 233, 241-42 n.2 (4th Cir. 1997), the court ultimately decided that the Brandenburg standard does not apply to teaching speech, a ruling that effectively rendered the defendant's stipulations irrelevant. See id. at 243 ("[W]e hold, as urged by the Attorney General and the Department of Justice, that the First Amendment does not pose a bar to a finding that Paladin is civilly liable as an aider and abetter of Perry's triple contract murder."). 
nocent, lawfully useful speech," in which the speaker did not specifically intend the information to be used for bad purposes. ${ }^{173}$ Conversely, the Fourth Circuit would remove constitutional protection from the speech of "those who would, for profit or other motive, intentionally assist and encourage crime." ${ }^{174}$ The Fourth Circuit's concession that some communication of information would still be protected by the First Amendment despite the inapplicability of Brandenburg does little to allay concerns about the effect of the Fourth Circuit's ruling on the Constitutional protection of political speech. In fact, this concession does little more than undercut the basic rationale for proscribing the dissemination of dangerous information to begin with.

The Fourth Circuit's approach threatens to undermine Brandenburg by converting every trial over the legality of teaching or informational speech into a trial about the speaker's intent in communicating the potentially dangerous information. Since the speaker's intent will often be found in statements that bracket the information, the decision whether to protect the dissemination of potentially dangerous information will often depend on whether the information is communicated along with radical political advocacy, antisocial messages, or other sorts of challenges to the status quo. Under such a standard, information concerning the profession of a hit man would be protected if it were packaged in a popular television program or movie, but exactly the same information would be subject to legal liability if reprinted and distributed in a book containing a preface praising the amorality of the professional assassin and encouraging others to pursue this line of work. The Fourth Circuit's standard would return this particular branch of First Amendment law to an approach reminiscent of political speech trials in the early years of the twentieth century, in the sense that courts and juries would once again be encouraged to punish speakers based on the odious nature of their ideas.

Not only does this approach undercut Brandenburg, it also renders senseless any attempt to allow the government to proscribe the dissemination of information because that information may be dangerous. The sole justification for suppressing teaching or informational speech such as "oral advice, training exercises, and perhaps the preparation of written materials" is that such speech "may create signifi-

$173 I d$. at 247 (" $[\mathrm{T}]$ he First Amendment may in some contexts stand as a bar to the imposition of liability on the basis of mere foreseeability or knowledge that the information one imparts could be misused for an impermissible purpose."). 
cant public danger." ${ }^{175}$ But if the decision whether a particular example of dangerous information may or may not be punished or censored depends solely on whether the person communicating that information is "for profit or other motive, intentionally assist[ing] and encourag[ing] crime," that the information itself is the problem. Creating a separate category for the control of "teaching speech" thus becomes merely a mechanism for circumventing the protection of political speech under Brandenburg.

At the end of the day, proponents of regulating teaching and instructional speech under a lower constitutional standard have failed to demonstrate why the various aspects of the Brandenburg paradigm should not apply to teaching speech as well as routine political advocacy. As noted above, the arguments for regulating teaching speech under a lower constitutional standard do not really focus on the nature of the information being communicated in that speech. Rather, the real focus is on the intent of the speaker in communicating information. There is no explanation why relatively innocuous information should be regulated under a lower standard simply because the speaker has bad motives. After all, the speakers in many of the Court's political advocacy cases also had bad motives, in the sense that they all proposed violent or illegal activity. The fact that bad motives are tied to speech of a factual nature as opposed to speech cast in the form of advocacy does not remove that speech from the assumptions embedded in the Brandenburg paradigm.

The key to the Brandenburg paradigm is that speech should only be regulated if it creates immediate and serious harm. The information communicated in the two cases raising these issues-Rice and $M c C o y-$ does not come close to meeting this standard. In Rice, the court dealt with a book whose author did little more than compile from the popular media information that was neither subtle nor particularly ingenious. ${ }^{177}$ It does not take great skill as a trainer of assassins to figure out that a hit man should not drive his or her own car to the site of a job. ${ }^{178}$ The information communicated in McCoy was even more obvious. Would it really have been news to any member of any gang anywhere in the country that spraying graffiti on walls in the

\footnotetext{
175 McCoy, 537 U.S. at 995 (Stevens, J., respecting denial of certiorari).

176 Rice, 128 F.3d at 248.

177 See Montgomery, supra note 143, and accompanying text.

178 See Rice, 128 F.3d at 240 (describing the instructions for assassins in the book Hit Man).
} 
gang's neighborhood would announce the presence of that gang? ${ }^{179}$ The fact is, the information in both Rice and McCoy was for the most part mundane, unoriginal, and widely available elsewhere. The information falls far short of creating the kinds of immediate harms required by the Brandenburg paradigm, and no good explanation exists for why we should fear the dissemination of this fairly mundane information so much that it justifies lowering the constitutional standard.

The courts have not explained why we should have a lower constitutional standard for protecting expression containing information than for expression advocating certain policies or principles. But, drawing logically from courts' statements, expression containing information should be suppressed more freely because we fear what the recipients will do with the information. Without a doubt, there is reason to fear what bad people will do with dangerous information. The question, however, is whether we have more to fear from information than from advocacy. In other words, do we have more reason to fear what the hypothetical bad person will do with dangerous information, or do we have more reason to fear what that same person will do after being exposed to violent advocacy that expressly instigates the very bad acts that society fears? In terms of legitimate social fears of bad consequences stemming from incendiary speech, for example, is it worse for a speaker in the Claiborne Hardware scenario to rile up audience members to beat up people who violate the economic boycott favored by the speaker, or is it worse for a speaker to describe to the audience members what type of bludgeon to use in the beatings?

The Brandenburg paradigm resolves these questions by prohibiting the government from regulating speech based on assumptions about what bad people will do after hearing provocative speech. The paradigm does not assume that there will never be bad consequences from speech, it simply establishes a regime in which the responsibility for those bad consequences will rest with the person doing the illegal act, not the speaker. The question is why that assumption should change when the expression in question contains information as opposed to advocacy. Why should we allow the government to paternalistically assume that people are incapable of dealing with information that may be put to bad purposes when we do not allow the government to paternalistically protect people from speech that expressly

179 See McCoy, 282 F.3d at 630 (noting that the defendant advised his friends to increase their "tagging" activities). 
endeavors to create the inclination to pursue those bad purposes? If the government is constitutionally obligated to trust listeners to be capable of rejecting the express advocacy of illegal behavior, then logically the government should also be constitutionally obligated to trust listeners to be capable of reading or listening to information without using that information for illegal or antisocial ends.

\section{The Regulation of Sexually Explicit Speech}

Both the true threats and teaching speech categories involve speech that is closely related to political advocacy. The Court has created several other content-based speech regulation categories that do not relate directly or indirectly to political expression or advocacy. Obscenity is one of the most prominent examples of a nonpolitical, content-based speech regulation category. Since the Court entered this arena in 1957, it has returned repeatedly to this category of speech, constantly reconfiguring the standard that applies to the regulation of speech within the category, sometimes subdividing sexually explicit speech into different subcategories with different standards, and often issuing opinions that directly contradict many of the concerns that the Court expressed in its political speech cases. The issue, then, is whether the principles and concerns embodied in the Brandenburg paradigm logically apply to the regulation of nonpolitical speech. A brief rendition of the Court's obscenity jurisprudenceincluding a recent foray into the area in a case that closely resembles the Court's advocacy decisions-will indicate that the Court could profit greatly from applying Brandenburg to this seemingly unrelated area of speech.

For purposes of this discussion, it is unnecessary to move beyond the Court's general obscenity standard, the much more lenient standard the Court applies to obscenity produced with children, and the Court's recent decision to permit the government to prosecute the "pandering" of sexually themed speech that otherwise is constitutionally protected. The Court's general obscenity standard is, in constitutional terms, a relatively recent innovation. The Court did not produce an opinion on the constitutional protection of sexually explicit speech until 1957, when it issued its decision in Roth $v$. United States. ${ }^{180}$ Prior to that, most American courts adjudicating obscenity prosecu-

180354 U.S. 476, 492 (1957) ("[W]e hold that these statutes, applied according to the proper standard for judging obscenity, do not offend constitutional safeguards against convictions based upon protected material, or fail to give men in acting adequate notice of what is prohibited."). 
tions had employed a standard derived from a nineteenth-century decision by the British House of Lords, Regina v. Hicklin. ${ }^{181}$ Hicklin produced a moral corruption standard for the regulation of sexually explicit materials. Hicklin is usually viewed as standing for the proposition contained in Lord Cockburn's opinion, which stated the following standard: "the test of obscenity is this, whether the tendency of the matter charged as obscenity is to deprave and corrupt those whose minds are open to such immoral influences, and into whose hands a publication of this sort may fall." ${ }^{182}$ There are multiple problems with this standard, including the fact that it presumes a degree of governmental authority to regulate morality, it sets the standard for corruption at the level of the most susceptible persons in society, and it contains no exemption for sexually explicit expression in works of legitimate art or literature. Nevertheless, with occasional complaints from lower court judges about the Victorian nature of this standard ${ }^{183}$ Hicklin provided the model for obscenity prosecutions in American courts until the mid-1950s.

When the Supreme Court finally got around to applying the First Amendment to sexually explicit speech in Roth v. United States, ${ }^{184}$ it modified the mechanics of Hicklin without abandoning Hicklin's emphasis on the government's need to regulate morally corrupting expressive materials. The Court did not prohibit the government from regulating obscenity; indeed, it reiterated the proposition that obscenity is not protected by the First Amendment at all. ${ }^{185}$ This reaffirmed what the Court had stated in dicta fifteen years earlier, that certain kinds of speech-such as the lewd and the obscene- "are no essential part of any exposition of ideas, and are of such slight social value as a step to truth that any benefit that may be derived from them is clearly outweighed by the social interest in order and morality." ${ }^{186}$ The Roth Court also did not prohibit the government from regulating speech that deviates from the dominant ethos of the community. Indeed, protecting the dominant ethos of the community is at the heart of the Roth standard, which establishes as the test for con-

181

(1868) 3 L.R.Q.B. 360.

Id. at 371 .

See, e.g., United States v. Kennerley, 209 F. 119, 120 (S.D.N.Y. 1913) (responding to Hicklin, Judge Learned Hand stated, "I hope it is not improper for me to say that the rule as laid down, however consonant it may be with mid-Victorian morals, does not seem to me to answer to the understanding and morality of the present time").

354 U.S. 476.

See id. at 485 ("We hold that obscenity is not within the area of constitutionally protected speech or press.").

See Chaplinsky v. New Hampshire, 315 U.S. 568, 572 (1942) (citation omitted). 
stitutionally unprotected obscenity "whether to the average person, applying contemporary community standards, the dominant theme of the material taken as a whole appeals to prurient interests." ${ }^{187}$

Nothing that the Court has done since 1957 has removed this aspect from its obscenity jurisprudence. The Court revisited its definition of obscenity several times in the decades following Roth, but it only managed to produce different variations on the themes Roth introduced. ${ }^{188}$ References to the "average person," "community standards," and materials appealing to "prurient interests" continue to be mainstays of the Court's obscenity jurisprudence to the present day. By the time the Court got around in 1973 to redefining the obscenity standard for what is, to date, the final time, the components of the standard had been well-honed. It says something about the relative illiberality of the standard developed during the Warren Court era that the more conservative Burger Court did not have to make major changes in the constitutional analysis or the underlying constitutional theory that supported it.

The components of the new constitutional definition of obscenity can be found in Miller $v$. California. ${ }^{189}$ The three-part Miller test requires the government to prove that purportedly obscene materials are "prurient" according to "the average person" applying "contemporary community standards," are patently offensive, and lack "serious literary, artistic, political, or scientific value." 190 Although there are multiple problems with this analysis, ${ }^{191}$ the more interesting matter for present purposes is the Court's discussion of its rationale for

Book Named "John Cleland's Mem Mass., 383 U.S. 413, 418 (1966) (Brennan, J., plurality opinion) (restating the constitutional test for obscenity to include: (1) prurient appeal; (2) patent offensiveness; and (3) that the material be utterly without redeeming social value); Jacobellis v. Ohio, 378 U.S. 184, 191-92 (1964) (Brennan, J., plurality opinion) (holding that obscene work must be "utterly' without social importance"); Manual Enters., Inc. v. Day, 370 U.S. 478, 486 (1962) (noting that obscene material must have the element of "patent offensiveness" in reference to "customary limits of candor"). 413 U.S. 15 (1973).

190 Id. at 24 ("The basic guidelines for the trier of fact must be: (a) whether "the average person, applying contemporary community standards' would find that the work, taken as a whole, appeals to the prurient interest; (b) whether the work depicts or describes, in a patently offensive way, sexual conduct specifically defined by the applicable state law; and (c) whether the work, taken as a whole, lacks serious literary, artistic, political, or scientific value." (citations omitted)).

191 For example, what does "prurient" mean, and how are jurors supposed to define a word that many of them have never heard before; who is an "average" person; what do the words "contemporary" and "community" mean in the phrase "contemporary community standards;" and how does one distinguish between "serious" and non-serious literature or art? 
permitting the government to continue suppressing expression simply because that expression deviates from the community's moral norm.

Much of this discussion is contained in a companion case to Miller, Paris Adult Theatre I $v$. Slaton. ${ }^{192}$ The case involved an adult theater, which screened sexually explicit films to an audience of consenting adults. Both the lower courts and the Supreme Court assumed that the theater had successfully barred minors from entering and had displayed adequate warnings to adults concerning the nature of the films shown. ${ }^{193}$ The argument on behalf of the theater, therefore, was that in the absence of any harm to consenting adults, the exhibition of obscene films to a willing audience should not be subject to regulation under the First Amendment.

In Paris Adult Theatre, the Court definitively rejected this consenting-adults notion of First Amendment rights. "[T] his Court has never declared [the protection of juveniles and unconsenting adults] to be the only legitimate state interests permitting regulation of obscene material." ${ }^{194}$ The Court makes a passing reference to a harm rationale for regulating obscenity before acknowledging that "there is no conclusive proof of a connection between antisocial behavior and obscene material." ${ }^{195}$ The Court's primary emphasis, therefore, is an explicit endorsement of the morality principle-that is, the principle that the government has the authority to embrace a particular view of morality and enforce it through the law. There are numerous references in the decision to concepts such as the "right of the Nation and of the States to maintain a decent society," 196 and the authority of the government to concern itself with "the tone of the society, the mode, or to use terms that have perhaps greater currency, the style and quality of life, now and in the future." ${ }^{197}$ The Court even suggests at the end of its opinion that what is being regulated in these cases may not deserve to be called communication at all. ${ }^{198}$ Control of obscene expressive materials, the Court contends, "is distinct from a control of reason and the intellect," and " $[\mathrm{w}]$ here communication of ideas, protected by the First Amendment, is not involved ... the mere fact that,

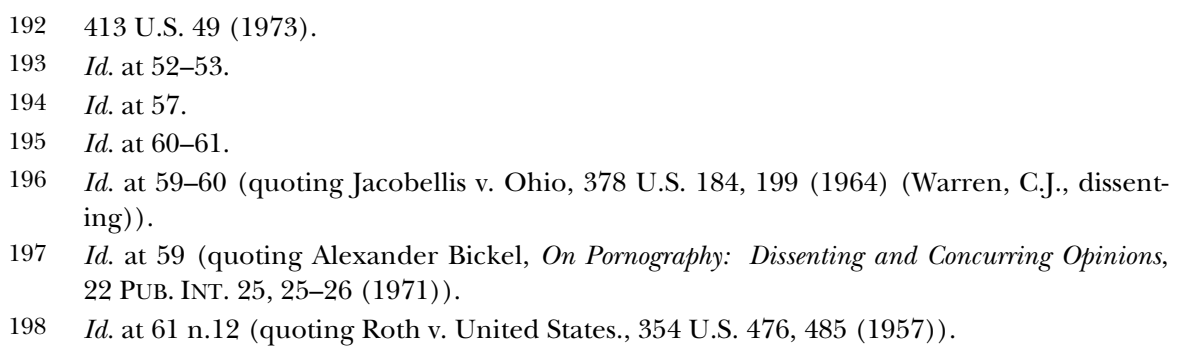


as a consequence, some human 'utterances' or 'thoughts' may be incidentally affected does not bar the State from acting to protect legitimate state interests." ${ }^{199}$

This represents perhaps the ultimate deviation from the Brandenburg paradigm of speech regulation: concrete harms resulting from speech are not a prerequisite to the regulation of that speech; to the extent that concrete harms stemming from speech are part of the analysis at all, such harms may be assumed by the state and need not be proven-much less proven to be an immediate threat to the public order; and finally, speech that falls outside the government's certification as "serious" need not be considered speech at all without regard to the fact that "some human 'utterances' or 'thoughts' may be incidentally affected." This regulatory regime is virtually unrecognizable as arising from the same constitutional amendment as Brandenburg. Nevertheless, Miller and Paris Adult Theater do not represent the nadir of constitutional protection for sexually explicit speech. There is yet another batch of precedents dealing with sexually explicit speech involving minors, in which the Court once again confronts the tension between the morality principle and the harm principle for regulating speech.

The Court's first efforts involving obscenity and minors definitively endorsed the morality principle. In New York v. Ferber, ${ }^{200}$ the Court upheld a New York child pornography statute without requiring the state to satisfy the obscenity standards set forth in Miller. The Court held that the first two components of Miller-the prurience and patent offensiveness elements-do not apply to the prosecution of child pornography. ${ }^{201}$ The Court even suggested that the third component of Miller-the artistic value element-may not apply to child pornography $^{202}$ (though the Court contradicted itself later in the opinion by noting that presumptively protected artistically or scientifically worthwhile materials would not amount to more than "a tiny fraction of the materials within the statute's reach"). ${ }^{203}$ Other than leaving these materials open to prosecution with virtually no constitutional protection, the most significant thing about the Ferber opinion is the Court's emphasis on permitting broad regulation of speech in order to shut down the market for certain expressive preferences. "The most expeditious if not the only practical method of

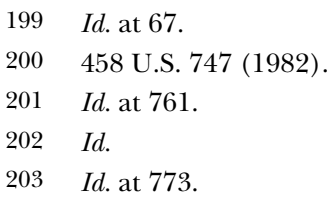


law enforcement may be to dry up the market for this material by imposing severe criminal penalties on persons selling, advertising, or otherwise promoting the product." ${ }^{204}$ The Court would later reinforce this proposition by refusing to apply to child pornography the protections offered in Stanley v. Georgia, ${ }^{205}$ which permits individuals to possess legally obscene materials at home. ${ }^{206}$

The implications of the Court's market-based theory of speech regulation are very broad. Taken to its limit, the notion that the government may seek to proscribe speech in order to eliminate particular antisocial preferences would permit the government to regulate more than merely speech containing explicit depictions of antisocial preferences. Logically, this notion would also allow the government to regulate any other speech-including legal speech-that feeds the preferences that the government is trying to eliminate. Thus, in the child pornography area, this rationale would permit the government not only to regulate obscene materials that were produced using actual children, but also materials using young-looking adults, materials employing cartoons or computer-manipulated imagery, or even materials using the written word to describe situations involving children engaged in sexual activity.

The government tried to do precisely this in the Child Pornography Prevention Act of 1996 (CPPA), ${ }^{207}$ only to have the Court strike down the statute and renounce much of what it had previously said in Ferber about the government's ability to control antisocial preferences through the regulation of speech. The entire tone of the Court's opinion in Ashcroft $v$. Free Speech Coalition ${ }^{208}$ stands in stark contrast to the tone of Ferber. The majority opinion in Ferber is written as if the rules governing the government's regulation of low-value speech have no connection whatsoever to the restrictions on government regulation of speech in the Court's high-value speech cases such as Brandenburg. In Free Speech Coalition, on the other hand, the Court not only draws heavily on the principles developed in the political speech area, it even cites several of the political speech cases to support its holding regarding the regulation of speech that is far removed from political advocacy. ${ }^{209}$

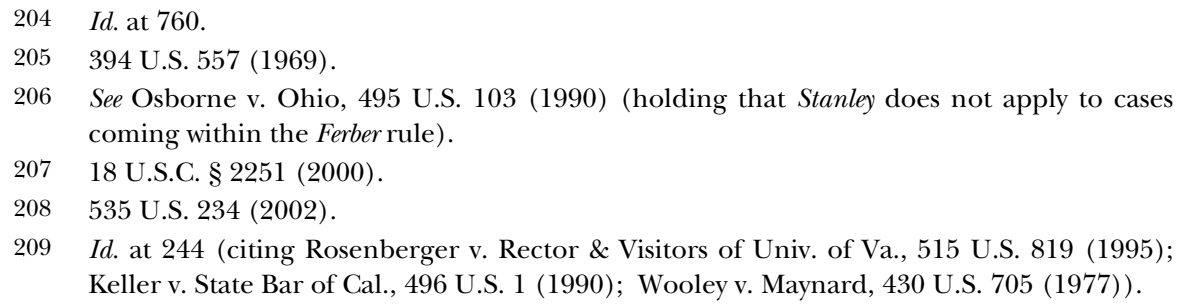


The CPPA prohibited possession or distribution of any image in any medium that "is, or appears to be, of a minor engaging in sexually explicit conduct." 210 In striking down this provision of the CPPA, the Court in Free Speech Coalition essentially limited Ferber to its facts, by adopting a concrete harm rationale for regulating child pornography. Thus, the government continues to have authority to regulate the production, distribution, and possession of sexually explicit materials that were produced using actual children, because in those instances the expression would serve as a "permanent record of a child's abuse," the continued circulation of which "would harm the child who had participated." ${ }^{211}$ The government does not have authority, however, to regulate expressive materials produced without using actual children, even if the materials contain images that graphically depict what seem to be children engaged in explicit sexual activity.

The government's rationale for seeking the broader regulatory authority directly implicates the Brandenburg paradigm in several ways, and the Court responds to the government's argument by directly appealing to several components of the Brandenburg paradigm. The government's rationale for regulating sexually explicit speech that appears to but does not actually involve minors is that such speech "whets the appetites of pedophiles and encourages them to engage in illegal conduct." ${ }^{212}$ The Court rejects this rationale by drawing directly on the Court's political speech jurisprudence in three ways. First, the Court notes that "[t]he mere tendency of speech to encourage unlawful acts is not a sufficient reason for banning it." 213 Second, the Court reiterates that "[t]he normal method of deterring unlawful conduct is to impose an appropriate punishment on the person who engages in it." ${ }^{214}$ Finally, the Court concludes that the government could not be granted the authority to regulate speech when it had shown "no more than a remote connection between speech that might encourage thoughts or impulses and any resulting child abuse."215

In Free Speech Coalition, we can see the model for applying the Brandenburg paradigm outside the context of political speech. First, there is a reliance on the harm principle as the sole rationale for gov-

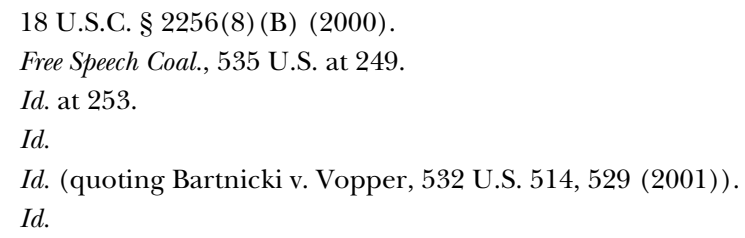


ernment regulation of speech. Second, there is an insistence that proof of harm must be definitive and the harm must be immediate"remote connections" between speech and bad conduct are not sufficient to justify regulating speech. Third, unless the speaker him or herself engages in the relevant bad conduct (in this case, by producing sexually explicit materials using actual children), then there is a total shift of responsibility for any bad acts from the speaker to the actor. Finally, and most importantly, there is a strong emphasis on the proposition that government attempts to control speech are really government attempts to control thought, which the government may do only as a last resort and only in the face of a dire emergency. There is a strong hint, therefore, that the prevailing free-speech jurisprudence is incompatible with the morality principle that has always governed the regulation of sexually explicit materials, first under Hicklin's conception that such materials may "corrupt those whose minds are open to such immoral influences," and later under the more nebulous Roth/Miller formulation that "prurient" and "patently offensive" materials are outside the scope of the First Amendment altogether.

If consistently applied, the approach taken by the Court in Free Speech Coalition would represent a hopeful sign that the Court was retreating from its embrace of a subdivided First Amendment, in favor of a more conceptually unified approach based on a more coherent theory of the proper role of human expression in a modern democracy. Unfortunately, the Court has never been consistent in these matters, least of all in the area of obscenity regulation. Contrast the approach taken by the Court in Free Speech Coalition, for example, with the approach taken by the Court in its most recent obscenity decision, United States v. Williams. ${ }^{216}$ Williams is a successor case to Free Speech Coalition. After the Court struck down much of the CPPA, Congress amended the statute to add a pandering section, which provides criminal penalties of up to twenty years in prison for anyone who "advertises, promotes, presents, distributes, or solicits ... material in a manner that reflects the belief, or that is intended to cause another to believe, that the material or purported material is, or contains ... a visual depiction of an actual minor engaging in sexually explicit conduct." ${ }^{217}$ The key to understanding the operation of this statute is that someone could violate the statute by "promoting" materials as containing visual depictions of actual minors even

\footnotetext{
216128 S. Ct. 1830 (2008).

21718 U.S.C. $§ 2252 A$ (a) (3) (B) (ii) (2006).
} 
though the material being promoted does not actually contain visual depictions of actual minors. In other words, someone could be convicted under the pandering section of the statue for promoting materials that are themselves constitutionally protected under Free Speech Coalition.

Just as the tone and approach of the Court's opinion in Free Speech Coalition deviated sharply from its earlier opinion in Ferber, the tone and approach of Williams deviates equally sharply from Free Speech Coalition. Only six years after producing an opinion that for all practical purposes renounced the long-standing theoretical basis of the Court's obscenity jurisprudence, the Court then turns around in Williams and essentially takes it all back. The Court even starts its opinion in Williams by expressly reaffirming the morality principle as applied to the regulation of obscenity: "We have long held that obscene speech-sexually explicit material that violates fundamental notions of decency-is not protected by the First Amendment." ${ }^{218}$ By authorizing the government to criminalize speech that runs contrary to political majority's "fundamental notions of decency," the Court implicitly renounces the application in obscenity cases of the ethical agnosticism mandate that is the linchpin of the Court's political speech jurisprudence. And having renounced the cornerstone of the Brandenburg paradigm, it is not difficult to understand why the Court would refuse to apply the remainder of that paradigm as well.

The defendant in Williams raised many of the aspects of the Brandenburg paradigm that the Court had already endorsed in Free Speech Coalition. In addition to the content regulation aspect of the paradigm, the defendant argued that the statutory provision at issue in Williams did not satisfy the harm principle (because the statutory prohibition was not limited to individuals possessing or disseminating materials using actual children), did not require the government to prove that the pandering speech led immediately to the relevant harm, and punished the speaker even though that speaker bore no responsibility for the ultimate illegal action (that is, the purchase or possession of materials containing depictions of children engaged in sexual activity). Williams is an exceedingly strange decision, in the sense that it permits government officials to outlaw one set of expressive materials simply for inaccurately referring to another set of expressive materials that the Court has declared constitutionally protected. The Court reaches this result based on "the principle that offers to give or receive what is unlawful to possess have no social 
value and thus, like obscenity, enjoy no First Amendment protection." ${ }^{219}$ The flaw in this logic is that if the offeror does not actually possess unlawful materials to begin with, then there is no possibility of that person doing anything that implicates the harm (i.e., distributing expressive materials depicting actual minors involved in sexual activity) that Free Speech Coalition identified to render the materials constitutionally unprotected. In Williams, the Court abandons the speech regime based on the harm principle, which it seems to have adopted in Free Speech Coalition, and returns to a regime that revolves around the morality principle, as evident in Hicklin, Roth, Miller, and Ferber.

To sum up the relationship between the Court's obscenity jurisprudence and the Brandenburg paradigm, except for one brief deviation in Free Speech Coalition, the Court has adhered closely to the notion that the government has the authority to use its power to regulate speech in order to advance the particular sexual ethos favored by the community's political majority. This model for speech regulation does not merely allow the government to advance a particular set of behavioral mandates, it also allows the government to favor certain aspects of the human personality. According to the Court, obscenity is unprotected by the First Amendment because it sought a reader who "looks for titillation, not... intellectual content." 220

Needless to say, this is deeply inconsistent with the predicates of the Brandenburg paradigm. The Brandenburg paradigm does not permit the government to use its authority to regulate speech to favor the majority's preferred set of ideas, precepts, or attitudes. Indeed, if the same social attitudes and ideologies that are embodied in obscenity are cast instead in the form of advocacy, the Court has agreed for over fifty years that the political speech standard applies. ${ }^{221}$ In other words, the advocacy of licentiousness is protected, but the depiction of licentiousness is not. If even the Court recognizes that sexual advocacy is on a par with political advocacy, then the Court's continued willingness to permit the government to regulate obscenity amounts to a form/content distinction. But if the Court is unwilling to accept that distinction in the context of government regulation of political

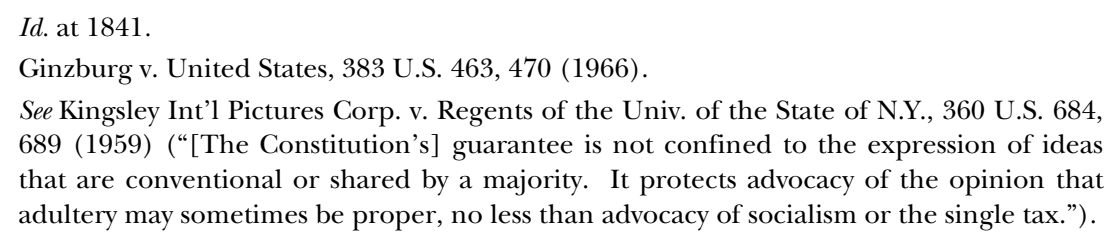


discourse using the word "fuck," 222 then why is it willing to accept the distinction in the obscenity context? The answer is that the Court has concluded that sexually explicit speech is different in kind from other speech that it considers more important. But that decision itself violates the central precept of the Brandenburg paradigm, which is that government agencies-a term that includes the courts-may not infuse the law with their own moral or political judgments about the relative value of one type of expressive content versus another. Ironically, the only way to justify leaving obscenity outside the protective umbrella defined by the Brandenburg paradigm is to violate the Brandenburg paradigm.

If the Court were to correct its inconsistent approach to the regulation of obscenity under the first part of the Brandenburg paradigm, then it would be quite easy to apply the rest of that paradigm to the government regulation of sexually explicit speech. The Court itself has provided a model for how to accomplish this in its Free Speech Coalition opinion. As in that opinion, the application of the Brandenburg paradigm would still permit the government to regulate obscenity if the government could demonstrate an actual, immediate, and concrete harm arising from the speech. Thus, the government clearly could regulate the possession and distribution of materials produced through coercion and could continue to regulate the possession and distribution of materials containing imagery of underage children participating in sexual activity. The government also could ensure that sexually explicit expressive materials were not distributed or displayed to unwilling adults or children. But it is deeply inconsistent with the Brandenburg paradigm for the government to outlaw expressive materials simply because they display imagery that a majority of the population finds morally repulsive or because the materials excite responses from viewers that relate to sex rather than more traditional intellectual concerns or interests.

\section{The Regulation of Student Speech in Public Schools}

The cases discussed in the previous three Sections have all involved situations in which the Court created a separate body of First Amendment jurisprudence that deviated from the Brandenburg paradigm because of the content of the speech being regulated. This is the most common way in which the Court has subdivided speech to avoid Brandenburg. But the Court has devised other avoidance me-

222 See Cohen v. California, 403 U.S. 15 (1971) (overturning the conviction of a man for wearing a jacket bearing the inscription "fuck the draft" in a public courthouse). 
chanisms, as well. In several sets of cases, for example, the Court has used the place or context in which the speech occurs to limit the protections that Brandenburg would otherwise offer for the same speech. One set of cases in which the context rather than the content of speech determines the degree of constitutional protection for that speech involves the speech of government employees. ${ }^{223}$ Another set of cases involves private persons whose speech is financed by the government. $^{224}$ A third set of cases involves the speech of students in public schools. This Section uses the school cases to consider whether the Brandenburg paradigm could reasonably be applied to situations in which the place, rather than the content of speech, determines First Amendment rights.

The Supreme Court has issued four opinions involving student speech, which are relatively easy to summarize, but much more difficult to reconcile. In the three content-based First Amendment subdivisions discussed above, some of the cases discussing these subdivisions directly incorporate many of the values present in the Brandenburg paradigm, while other opinions are written as if Brandenburg and the principles it embodies have no application whatsoever to the new category of speech. The same is true of the school speech cases. The Court started out by defining this area of law with close attention to the kinds of concerns that motivated Brandenburg. During the next forty years, the Court systematically abandoned those concerns in favor of an authoritarian approach under which the scope of student free speech diminished substantially in comparison with the government's power to control speech that runs counter to the perspective of government officials.

In the beginning, the Court made very little distinction between adult speech and student speech. The Court began its first decision on the subject in Tinker v. Des Moines Independent Community School District ${ }^{225}$ with a rousing reminder that students and teachers do not "shed their constitutional rights to freedom of speech or expression at the schoolhouse gate." 226 The rest of the opinion seems to indicate that the Court really meant it. The case involved a group of students who were suspended from school for wearing black armbands to pro-

\footnotetext{
223 See, e.g., Connick v. Myers, 461 U.S. 138 (1983) (setting forth the First Amendment standard for speech by public employees on matters of public and private concern).

224 See, e.g., Rust v. Sullivan, 500 U.S. 173 (1991) (setting forth the First Amendment standard for government restrictions on private individuals speaking on behalf of the government).

225393 U.S. 503 (1969).

$226 I d$. at 506.
} 
test the Vietnam War. While the Court recognized the school authorities' need to structure the school day and maintain discipline in the classroom, the Court also emphasized that an "undifferentiated fear or apprehension of disturbance is not enough to overcome the right to freedom of expression." ${ }^{227}$ The Court went on to note that the citizenship of student speech must be justified by "something more than a mere desire to avoid the discomfort and unpleasantness that always accompany an unpopular viewpoint." ${ }^{228}$ The Court also linked the censorship of student speech to constitutionally impermissible official attempts to indoctrinate the students. According to the Court, "state-operated schools may not be enclaves of totalitarianism," and students at those schools "may not be confined to the expression of those sentiments that are officially approved."229 The Court then produced a rule governing student expression at public schools that strongly resembles the Brandenburg immediate harm standard: "where there is no finding and no showing that engaging in the forbidden conduct would 'materially and substantially interfere with the requirements of appropriate discipline in the operation of the school,' the prohibition [on student speech] cannot be sustained." ${ }^{230}$ In sum, the Court's initial foray into the area of student speech produced something entirely compatible with the Brandenburg paradigm - a mandate of no content or viewpoint regulation; a recognition that speech may only be censored when that speech creates a concrete and immediate harm; a further recognition that although it is always possible that antagonistic or dissenting speech may start a disturbance, "our Constitution says we must take this risk;",231 and finally, a general acknowledgment that even underage students must be respected as capable of hearing ideas they do not like without immediately responding in antisocial ways.

After setting the stage by applying something akin to the Brandenburg paradigm to student speech, the Court then spent the next forty years taking back most of what it had said in Tinker. The next three cases in which the Court addressed the First Amendment rights of students ostensibly carved narrow exceptions out of Tinker. In reality, these three cases cut the heart out of Tinker, to the point that it is difficult to see how much, if any, of the holding of Tinker actually survives.

\footnotetext{
$227 I d$. at 508

228 Id. at 509

229 Id. at 511.

230 Id. at 509 (quoting Burnside v. Byars, 363 F.2d 744, 749 (5th Cir. 1966)).

231 Id. at 508 (citing Terminiello v. Chicago, 337 U.S. 1 (1949)).
} 
In Bethel School District No. 403 v. Fraser, ${ }^{232}$ for example, the Court upheld the suspension of a high school student who had used sexual innuendo in a speech nominating someone for an elected student government office. ${ }^{233}$ Although the Court's majority opinion describes the innuendo as "an elaborate, graphic, and explicit sexual metaphor," ${ }^{234}$ a review of the full text of the speech reveals that it fell far short of that description. ${ }^{235}$ Nevertheless, the Court ruled that the school had the authority to punish Fraser as part of its effort to inculcate in students the inappropriateness of using "vulgar and offensive terms in public discourse." $" 236$ In contrast to the adult world, the Court held that in the school context the authorities could impose an offensiveness standard on speech, such that speech may be censored if it offends others-even if the speech poses no threat of a serious disruption of the school's operations.

The notion that public schools can use censorship as a means of exercising control over the academic curriculum is also a central feature of the Court's next opinion dealing with student speech, Hazelwood School District v. Kuhlmeier. ${ }^{237}$ Kuhlmeier involved a public high school principal's decision to pull from the school newspaper two articles written by journalism students. ${ }^{238}$ One article dealt with student pregnancy and the other dealt with the effects of divorce on students. ${ }^{239}$ Both articles represented serious efforts to deal with these subjects in a mature way. The principal nevertheless pulled the articles based on his objections to the fact that the articles identified several of the persons mentioned and also that the articles discussed both sexual activity and birth control. ${ }^{240}$ Rather than treating this as simply as a matter of a newspaper publisher spiking a story that he did not like, the Court instead broadened its analysis to encompass student speech arising in any curricular context. Thus, the Court's own phrasing of the holding in Kuhlmeier is that "educators do not offend the First Amendment by exercising editorial control over the style and content of student speech in school-sponsored expressive

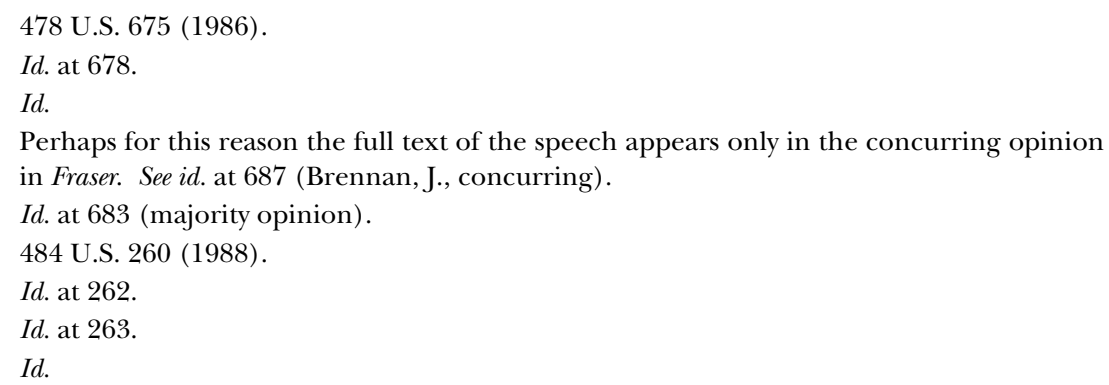


activities so long as their actions are reasonably related to legitimate pedagogical concerns." 241

At one level, this phrasing of the Kuhlmeier holding is uncontroversial. Certainly school officials have the authority to insist that students refrain from submitting in a biology class a term paper on the latest developments in the indie music scene. But at another level, Kuhlmeier performs radical surgery on Tinker. First, Kuhlmeier limits the Tinker disruption standard in the sense that it now applies only to noncurricular matters. This is a radical change because Kuhlmeier describes the school's curricular concerns in expansive terms: "activities may fairly be characterized as part of the school curriculum, whether or not they occur in a traditional classroom setting, so long as they are supervised by faculty members and designed to impart particular knowledge or skills to student participants and audiences." ${ }^{242}$ Elsewhere, the Court in Kuhlmeier refers several times to Fraser's concept of the curriculum as including instruction in matters of decorum and the inculcation of "the shared values of a civilized social order." ${ }^{243}$ This broad characterization of the public school curriculum raises the specter not only of students being punished for expressing in class disfavored views of some political or social policy but also the prospect of students being sanctioned for expressing dissenting views outside of class if those views deviate from the officially sanctioned "shared values of a civilized social order."

This latter possibility became reality in the Court's most recent student speech case, Morse v. Frederick. ${ }^{244}$ In this case the Court upheld the suspension of a high school student who held up a banner with the inscription "BONG HiTS 4 Jesus" across the street from his school at a time when the Olympic torch was passing by the school. ${ }^{245}$ The school's explanation for suspending the student was that the banner violated the school policy discouraging drug use, and that explanation was good enough for the Court. ${ }^{246}$ In First Amendment terms, the majority's decision in Morse is almost as cryptic as the student's message that gave rise to that case. The Court's decision rested on two propositions. First, from Tinker, Fraser, and Kuhlmeier, the Court synthesized the basic proposition that schools are different, in the sense that (quoting Fraser) "the constitutional rights of stu-

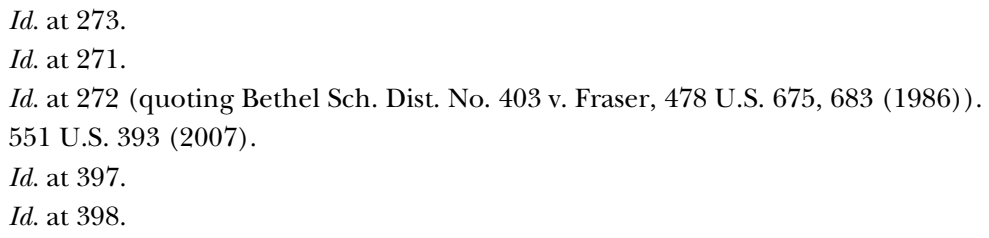


dents in public school are not automatically coextensive with the rights of adults in other settings." ${ }^{247}$ Second, the Court used several Fourth Amendment cases involving school searches to support its pronouncement that deterring drug use in schools is an "important" if not "compelling" state interest. ${ }^{248}$ From the Court's perspective, the combination of these two factors was sufficient to override any First Amendment interest and uphold the school's decision to suspend the student.

The difficulty with the Court's analysis in this case starts with the Court's acceptance of the school principal's interpretation of the meaning of the student's banner. First of all, it is by no means clear that the banner was intended to encourage drug use. A literal reading of the banner produces the conclusion that it was simple nonsense. In light of the nonsensical phrasing of the banner, the student's own explanation is enlightening. The student explained that the banner was phrased oddly in order to attract the attention of the television cameras that were on the street to record the Olympic torch. $^{249}$ All things considered, the student's explanation seems plausible, and the principal seems less like a conscientious disciplinarian and more like a Ferris Bueller character who did not quite get the joke.

Oddly enough, in some ways the principal's interpretation should have made the case more difficult for her to win. If the principal's interpretation of the banner were correct, it would be hard not to construe the banner as containing ideas worthy of First Amendment protection under Tinker. After all, under the principal's construction of events, the student was engaging in a discussion of a public policy issue, not only outside the classroom, but outside the school itself, in a public forum, in a manner that was not disrupting the school's educational mission. The bottom line is that the principal simply did not like the student's message. The principal responded to this interpretation of events with the incoherent assertion (which the Court seems to have accepted) that the student "was not disciplined because the principal of the school 'disagreed' with his message, but because his speech appeared to advocate the use of illegal drugs." ${ }^{250}$ But if, as the principal argued, the student was advocating the use of illegal drugs, then the student was disciplined precisely because the principal disagreed with his message.

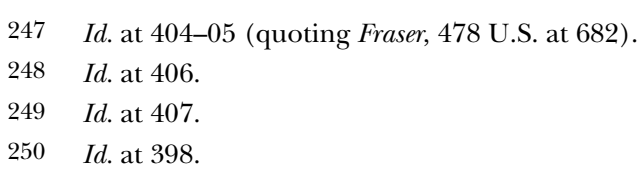


Nothing in the Morse decision ostensibly changes any of the Court's previous jurisprudence concerning student speech under the First Amendment. Two members of the majority in Morse even filed a concurring opinion emphasizing that the decision did nothing to restrict student speech "that can plausibly be interpreted as commenting on any political or social issue, including speech on issues such as 'the wisdom of the war on drugs or of legalizing marijuana for medicinal use." ${ }^{251}$ This attempt to assuage the concerns of student speakers does little to help the majority, since it suggests the unlikely prospect that the Court would have protected the student's speech in Morse if the student had added the words "Students Should Have the Right to Say" above the words "BONG HiTS 4 Jesus." The concurring opinion also does little to help the majority explain why the Court feels it has the authority to create a special rule for speech regarding drugs. The best the concurring opinion can do is assert that "illegal drug use presents a grave and in many ways unique threat to the physical safety of students." ${ }^{252}$ Unfortunately, this part of the concurring opinion flies directly in the face of the longstanding First Amendment recognition that discussing something is entirely different than doing it.

Morse demonstrates that abandoning the Brandenburg paradigm even in a particular factual setting such as schools leads the Court away from disciplined oversight of arbitrary administrative authority and robs the Court of any framework within which to explain what speech is constitutionally protected and what speech is not. In fact, all of the Court's legitimate concerns about the need to regulate student speech in the public school context can easily be addressed within the Brandenburg paradigm. Three legitimate concerns surface in the school speech context: the need to prevent disruption of academic activities; the need to prevent student speech that could be attributed to the school and cause the school legal or other difficulties; and the need for the school to control the content of its curriculum. Each of these can be addressed within the Brandenburg paradigm.

The need to prevent disruption is the easiest to address. As Tinker itself recognizes, the term disruption cannot be interpreted so broadly as to include verbal disagreements or heated discussions of issues about students. The Court only gives schools the authority to regulate serious disruption. ${ }^{253}$ If this term is interpreted to include

Id. at 422 (Alito, J., concurring) (quoting Stevens, J., dissenting).

Id. at 425 .

Tinker v. Des Moines Indep. Cmty. Sch. Dist., 393 U.S. 503 (1969). 
the verbal or physical interruption of classroom activities, then control of such activities can easily be carried out within the terms of the Brandenburg paradigm. Nothing within the Brandenburg paradigm permits a speaker to disrupt the activities of others, and the paradigm clearly permits government to direct speech away from locations where speech is incompatible with other uses of the particular forum. ${ }^{254}$ Conversely, the Brandenburg paradigm provides helpful mechanisms for enforcing the schools' obligation to permit student speech that does not result in a serious disruption of academic affairs. Tinker's focus on serious disruption of classroom activities is compatible with the Brandenburg paradigm's focus on the need for government to identify an immediate threat of concrete harm before suppressing speech. Likewise, the Brandenburg paradigm's emphasis on listener responsibility coincides with the educational system's emphasis on encouraging students to exercise their intellects and explore alternative perspectives on reality.

Just as Tinker complements the Brandenburg paradigm, Brandenburg is compatible with the school's interest in preserving control over its own speech and its curriculum. The Brandenburg paradigm does suggest, however, that there should be severe limitations on the efforts of schools to expand the concept of curriculum so much that they are able to exercise control over virtually every aspect of a student's life while at school. Thus, while a school certainly has the authority to educate students in subjects such as civics, history, philosophy, and political science, these subjects must be taught with a recognition of the student's right to express his or her opinion on basic moral issues and the topics of the day. Similarly, in situations analogous to the facts in Kuhlmeier, the school authorities must take the writer's free speech into account when exercising control over forums for student expression such as student newspapers, magazines, and student assemblies. The Brandenburg paradigm strongly suggests that a school board may not, on one hand, announce to its students that it "will not restrict free expression or diverse viewpoints within the rules of responsible journalism," ${ }^{255}$ and then turn around and restrict free expression and suppress the viewpoints of students with which the authorities disagree.

\footnotetext{
254 See Grayned v. City of Rockford, 408 U.S. 104, 116 (1972) ("The crucial question is whether the manner of expression is basically incompatible with the normal activity of a particular place at a particular time.").

255 Hazelwood Sch. Dist. v. Kuhlmeier, 484 U.S. 260, 277 (1988) (Brennan, J., dissenting) (citation omitted).
} 
The implications of the Brandenburg paradigm deviate most sharply from the Court's current approach to school speech cases in situations analogous to Fraser and Morse. Under the Brandenburg paradigm, some evidence of an immediate and concrete harm-such as a serious disruption of the school's educational activities-would be necessary to suppress student speech outside the classroom. No evidence of such disruption was evident in either Fraser or Morse. Although one could conceive of situations in which a student's use of vulgarity in a classroom situation could disrupt the educational enterprise-and therefore could be regulated or prohibited-the blanket prohibition of vulgarity in situations outside the classroom cannot be defended under the Brandenburg paradigm.

Since disruption is not an issue in situations such as Fraser, attempts to defend a school's regulation of speech such as that used by Mr. Fraser must therefore depend on similar arguments to those used by the school in Morse. In other words, the school must claim that in addition to its function in educating students about traditional academic subjects, the school also has a role in enforcing on students mainstream notions of civility (as in Fraser) and requiring from students absolute fealty to the official position regarding controversial issues of the day, such as the recreational use of drugs (as in Morse). Unfortunately, this definition of the school's extra-educational role violates several central First Amendment precepts about the intellectual independence of the citizenry. These precepts are embodied in the portions of the Brandenburg paradigm that refer to the assumption of listener acumen and incredulity. Complementing the First Amendment mandate that the government respect the listener's independence is the equally important mandate that the government must protect the speaker's independence, in the sense that the speaker should be allowed to determine for him or herself how to communicate his or her ideas.

The significant question in the school speech cases is whether these precepts, as embodied in the Brandenburg paradigm, should be diluted or abandoned with regard to persons who have not yet reached adulthood. When the issues are reduced to their essence, the answer should be no. This conclusion follows from the fact that under the Brandenburg paradigm, any student speech that disrupts the educational enterprise of a school may be suppressed by that school. Once the possibility of disruption is removed from the equation, we are left with a situation in which government officials are seeking to coerce citizens (albeit young citizens) to parrot the official position on a range of public policy issues and matters of public decorum. Under the Brandenburg paradigm this is an unacceptable use 
of government power, and there is no good reason why the age of the person being coerced would alter the free speech analysis. Even two members of the Morse majority recognized that the First Amendment is incompatible with efforts to broadly construe the public school's educational mission to include control over student opinions and the speech expressing those opinions: "The 'educational mission' argument would give public school authorities a license to suppress speech on political and social issues based on disagreement with the viewpoint expressed. The argument, therefore, strikes at the very heart of the First Amendment." ${ }^{256}$

This acknowledgment of limitations on the schools' educational mission implicitly recognizes a sharp distinction between education and indoctrination. Under the First Amendment, schools must always do the former but may never do the latter. Unfortunately, the majority failed to apply this distinction to the facts of Morse itself. The notion that the school banned the student's speech in order to protect the physical safety of the students is absurd, because speech is different than action. The notion that the student's speech somehow was part of the school's educational mission is equally absurd, given the fact that the speech occurred outside of class and related to no subject in the curriculum. We are left in Morse with a situation in which the school asserted as a matter of policy one point of view on a public policy issue and the student got suspended for asserting a contrary point of view. Since even the Morse majority seems to acknowledge that students have a First Amendment right to express political points of view, ${ }^{257}$ little is left of the majority's rationale for ruling in favor of the school.

Once one recognizes that schools may never use their educational mission as a license to instill the government's preferred values in students, then there is no good theoretical distinction to be made between the school speech cases and the adult speech cases that are currently governed by Brandenburg. In both situations, the question is whether the government may use its authority to control dangerous actions as an excuse to suppress what it believes to be dangerous thoughts. The Brandenburg paradigm is predicated on the notion that it is incompatible with democratic self-governance for the government to control expression as a means of controlling the thoughts of citizens. If this is an accurate description of what the government is doing in the school speech cases, then the Court's current approach

\footnotetext{
256 Morse, 551 U.S. at 423 (Alito, J., concurring).

257 Id. at 403-04 (reaffirming Tinker).
} 
to student speech in public schools gives the authorities too much power over expression and student thought. Conversely, if Brandenburg would permit school officials to fulfill their educational responsibilities by preventing disruption of the educational atmosphere, then the school speech cases could easily be brought within the ambit of the Brandenburg paradigm without damaging the schools' legitimate functions. The only downside to doing so would be to force school officials to tolerate certain examples of student speech with which they disagree. This is hardly an argument against applying the Brandenburg paradigm to the school context, however; it simply brings the constitutional obligations of government educators into line with the obligations that already apply to the rest of the government.

\section{FEAR OF Rights: THE CASE AgAinst SubDIVIDING THE FIRST AMENDMENT}

The four categories of speech discussed in the previous Part represent examples of what Harry Kalven, Jr. once labeled the "two-level theory" of free expression protection under the First Amendment. ${ }^{258}$ This theory holds that there should be one level of protection for political speech and advocacy and another level of protection for nonpolitical speech. In the modern era, this has mutated into the "multileveled theory" of free expression protection, since the Supreme Court has created multiple categories of First Amendment jurisprudence to cover different types of speech. The Supreme Court has never offered a theoretically sophisticated explanation for subdividing the First Amendment in a way that provides a much lower level of protection for nonpolitical speech than for political speech. Academics have attempted to fill this gap with several explanations of their own.

Kalven coined his term in response to the Court's first obscenity decision in Roth $v$. United States. ${ }^{259}$ Roth was litigated by both the petitioner and the government as a clear and present danger case-in other words, as if it were covered by the terms of what would later become the Brandenburg paradigm. ${ }^{260}$ Justice Douglas interrogated the government attorney in Roth closely about whether the pertinent

Harry Kalven, Jr., The Metaphysics of the Law of Obscenity, 1960 SuP. CT. REV. 1, 10. 354 U.S. 476 (1957).

260 For two accounts of the oral argument in Roth, see EDWARD DE GRAZIA, GIRLS LEAN BACK EvERYWHERE: THE LAW OF OBSCENITY AND THE ASSAUlT ON GENIUS 298-318 (1992); Matthew Benjamin, Possessing Pollution, 31 N.Y.U. REv. L. \& Soc. Change 733, 734-36 (2007). 
clear and present danger was the danger of "be[ing] shocked." ${ }^{261}$ The government attorney responded by citing a series of dangers, including the long-term behavioral changes brought on by the "breaking down of morals." ${ }^{62}$ This discussion became irrelevant, however, when the Court decided to adopt Felix Frankfurter's view that the clear and present danger analysis did not even apply, since obscenity was outside the Constitution altogether. This approach harkens back to two earlier opinions in which the Court refused to apply the clear and present danger analysis to nonpolitical speech. ${ }^{263}$ In both cases the Court's rationale is little more than the ipse dixit that the speech in question did not fall within the Constitution and therefore could not claim the protection of the Court's political advocacy jurisprudence. The most famous articulation of this theme appears in Chaplinsky v. New Hampshire.

There are certain well-defined and narrowly limited classes of speech, the prevention and punishment of which have never been thought to raise any Constitutional problem. These include the lewd and obscene, the profane, the libelous, and the insulting or 'fighting' words-those which by their very utterance inflict injury or tend to incite an immediate breach of the peace. It has been well observed that such utterances are no essential part of any exposition of ideas, and are of such slight social value as a step to truth that any benefit that may be derived from them is clearly outweighed by the social interest in order and morality. ${ }^{264}$

The Chaplinsky formulation that certain kinds of speech are outside the First Amendment altogether relieves the government of demonstrating interests of a sufficient type and magnitude to satisfy the government's obligations under the Brandenburg paradigm, but it fails to explain why certain kinds of speech are deemed low-value. Instead of explaining why the government has the authority to seek control over certain types of thought and expression by its citizens, the Court just says so.

To the extent that the Chaplinsky Court offers any explanation of the "two-level" theory of the First Amendment, that explanation may now be obsolete in light of more recent developments in the Court's free speech jurisprudence. In the quotation above, the Court implies that there are three reasons for placing certain types of speech outsent danger analysis to a criminal libel statute); Chaplinsky v. New Hampshire, 315 U.S. 568, 571-72 (1942) (declining to apply the clear and present danger analysis to fighting words). 
side the First Amendment. The first is that some kinds of speech "are no essential part of any exposition of ideas." ${ }^{265}$ This rationale cannot survive Cohen v. California, in which the Court recognized that the First Amendment protects the expression of emotions to the same extent as it protects the expression of ideas. ${ }^{266}$ The second and third reasons the Chaplinsky Court offers for denying constitutional protection to some kinds of speech are that the value of some speech is outweighed "by the social interest in order and morality." 267 The government's interest in protecting social order is no reason to exclude speech from the protection of the Brandenburg paradigm, because that paradigm by its very terms protects the government's interest in preserving order. The Brandenburg paradigm protects speech only until that speech presents a clear and present danger of immediately disrupting the social order. Chaplinsky's final rationale-that the government has an interest in suppressing individual liberty such as free expression in order to protect the community's collective morality-no longer carries weight in light of two developments subsequent to Chaplinsky: first, the Court's recognition that the government has no authority under the First Amendment to restrict expression attacking conventional morality, ${ }^{268}$ and second, the Court's extension of substantive due process privacy protection to those engaged in behavior that deviates significantly from society's moral mainstream. ${ }^{269}$

If the Court's explanation for the two-level theory of the First Amendment is unsatisfactory, academic attempts to provide alternative explanations fare no better. Many of these academic attempts focus on particular types of speech, arguing that they should not be subject to the same rigorous protection as political advocacy. For example, Frederick Schauer has argued that the Court should not protect sexually explicit materials under the First Amendment because obscene materials are not "speech." 70 These materials are not

\footnotetext{
265 Id. at 572.

266 See Cohen v. California 403 U.S. 15, 26 (1971) ("We cannot sanction the view that the Constitution, while solicitous of the cognitive content of individual speech, has little or no regard for that emotive function which, practically speaking, may often be the more important element of the overall message sought to be communicated.").

267 See Chaplinsky, 315 U.S. at 572.

268 See Kingsley Int'l Pictures Corp. v. Regents of the Univ. of the State of N.Y., 360 U.S. 684, 689 (1959) (extending First Amendment protection to moral as well as political advocacy).

269 See Lawrence v. Texas, 539 U.S. 558, 577-78 (2003) (striking down a Texas sodomy statute as a violation of the federal constitutional right of privacy).

270 See Frederick Schauer, Speech and "Speech"-Obscenity and "Obscenity": An Exercise in the Interpretation of Constitutional Language, 67 GEO. L.J. 899, 922 (1979).
} 
"speech," Schauer argues, because they do not engage the cognitive faculties, but rather are designed to elicit a purely physical effectsexual arousal. ${ }^{271}$ Along similar lines, Charles Lawrence argued several decades ago that verbal, racist insults (including those that do not fall into the traditional category of fighting words) should be deemed unprotected by the First Amendment because such speech "is experienced [by the target of the speech] as a blow, not a proffered idea, and once the blow is struck, it is unlikely that dialogue will follow." ${ }^{272}$ At the other end of the ideological continuum, Robert Bork famously argued that that the First Amendment should apply to nothing more than a narrow category of mainstream political speech. ${ }^{273}$ In Bork's blunt terms, "constitutionally, art and pornography are on a par with industry and smoke pollution." ${ }^{274}$

There are particular flaws specific to each of these proposals. With regard to Professor Schauer's proposal to exclude pornography from the First Amendment, for example, there is the problem that all speech requires mental intermediation to have any effect. Thus, treating sexually explicit speech as if it were functionally indistinguishable from a physical sex toy simply does not accurately reflect the complex reality of the expression in question. Other problems arise with regard to proposals to strip constitutional protection from racist insults and other hate speech. It violates every precept of democratic self-governance to single out certain content as being so inherently traumatic that the government cannot ever allow that content to be heard. Efforts to justify the government's censorship of hate speech on the ground that the content is socially dysfunctional cede to the government the deeply undemocratic authority to distinguish between good and bad content. Finally, Professor Bork's attempt to limit the First Amendment to a narrow category of mundane political speech fails on definitional terms. As Alexander Meiklejohn discovered in his early exploration of free speech theory, the isolation of explicitly political speech is an unsatisfactory way of limiting the scope of the First Amendment, given the extent to which other types

$271 \quad I d$

272 Charles R. Lawrence III, If He Hollers Let Him Go: Regulating Racist Speech on Campus, 1990 DUKe L.J. 431, 452.

273 Robert H. Bork, Neutral Principles and Some First Amendment Problems, 47 IND. L.J. 1, 20 (1971) (arguing that the First Amendment should protect only explicitly political speech, and that constitutional protection should be denied to all scientific, literary, and pornographic speech, as well as speech advocating illegal activity or forcible overthrow of the government). 
of speech influence political attitudes. ${ }^{275}$ If the First Amendment is primarily concerned with fostering the intellectual independence of an active and involved citizenry, then all speech must be protected, not just the speech of politicians.

Aside from their individual defects, these disparate efforts to carve certain types of speech out of the First Amendment share a deeply flawed common theme. This theme is to interpret the First Amendment as applying only to speech that is rational, moderate, emotionally muted, and inoffensive. In addition, all of the commentators discussed above seem to agree with the proposition that speech regarding mainstream politics and governance should be afforded special prominence within the First Amendment constellation. These commentators seem to regard all other types of speech as, at best, socially useless "casual chit-chat" (to borrow a phrase Richard Posner once used to describe speech that he refused to protect under the First Amendment ${ }^{276}$ ) and, at worst, socially harmful efforts to undermine the commonwealth. In Cass Sunstein's version of this theory, expression is covered by the First Amendment only if it is "intended and received as part of the exchange of ideas," and expression is protected under the highest standard only if it is "intended and received as part of public deliberation about some issue." ${ }^{277}$ The key to all these proposals is that once we move beyond the "core" of mainstream political speech, the usual First Amendment rules do not apply, or do not apply with sufficient rigor, to significantly limit the government's authority to restrict expression within peripheral categories of speech. "Under current doctrine, and under any sensible system of free expression, speech that lies at the periphery of constitutional concern may be regulated on a lesser showing of harm than speech that lies at the core." 278

275 Meiklejohn's theory of the First Amendment was based on the proposition that " $[\mathrm{t}] \mathrm{he}$ principle of the freedom of speech springs from the necessities of the program of selfgovernment." AleXander Meiklejohn, Political Freedom: The Constitutional POWERS OF THE PEOPLE 27 (1960). Despite his initial emphasis on the purely political focus of the First Amendment, Meiklejohn's later work extended the protection of the amendment to a range of nonpolitical expressive materials, including "novels and dramas and paintings and poems," on the theory that these nonpolitical materials contribute to the formation of political values that will eventually translate into direct political action such as voting. Alexander Meiklejohn, The First Amendment Is an Absolute, 1961 SUP. CT. REV. 245, 263. sons or otherwise confined to a small social group is unrelated, or largely so, to [the] marketplace [of ideas], and is not protected [by the First Amendment].”). 
The irony of these attempts to diminish the importance of all but mainstream political speech under the First Amendment is that the very effort to limit the scope of the Brandenburg paradigm to a narrower range of overtly political speech itself violates the Brandenburg paradigm. The Brandenburg paradigm requires the government to be agnostic with regard to the content of speech, permits the government to regulate speech only in situations where the speech presents an immediate danger of social upheaval, and requires the government to trust the good judgment of citizens to ignore speech that contains unhelpful, antisocial, or harmful content. Proposals to permit the government to regulate nonpolitical speech more aggressively than political speech violate each of these proscriptions.

The restrictions on the government that are embedded in the Brandenburg paradigm are not just functions of the political speech context in which Brandenburg arose, nor can it even be said that the spirit of the Brandenburg paradigm is anchored in the First Amendment alone. The Brandenburg paradigm is not just an assertion of the First Amendment or free speech rights, but rather a statement about the very nature of constitutional democracy itself. The Brandenburg paradigm embodies a larger vision of the role of government and the relationship between government and its citizens. It is not entirely accurate to see this vision as one of limited government. The Brandenburg paradigm would permit the government to be quite aggressive in implementing the goals and objectives of the democratically elected majority. The Brandenburg paradigm strictly limits government, on the other hand, in situations where the government tries to direct the citizenry in the identification of its chosen goals and objectives, or where a government dominated by those pursuing one set of ultimate goods attempt to foist their view of reality on those who persist in pursuing conflicting views of ultimate goods. Under the Brandenburg paradigm and the vision of constitutional democracy it embodies, government is the means to a chosen end; it is not the agent that chooses that end.

This vision of democracy explains each of the elements of the Brandenburg paradigm. It explains why the government is prohibited from engaging in content or viewpoint regulation of speech, why the government is prohibited from regulating a speaker except when that speaker threatens immediate harm to others, and why the government is required to respect the independent judgment of its citizens and is prohibited from engaging in any paternalistic regulation of speech. This vision of government also reflects a deeply rooted Holmesian skepticism about the possibility of achieving collective consensus about ultimate goods. Thus, citizens are expected to exer- 
cise independent judgment in arriving at their assessment of what ultimate goods society should pursue, even if that independent judgment leads them to conclusions that might be viewed by the rest of society as deeply antisocial or antithetical to the common good.

Contrary perspectives on the First Amendment, such as those discussed above, are deeply elitist assertions of power on behalf of the political majority controlling the government. This elitism sometimes comes to the surface expressly in the Court's decisions. In the school speech cases, for example, the Court justifies the suppression of student speech on the ground that the school has an obligation to teach students what to think about certain issues and how to express themselves in general. ${ }^{279}$ Likewise, in cases concerning the regulation of sexually explicit speech, the Court refers to such speech as infringing upon the majority's moral community. ${ }^{280}$ The case mentioned above in which Judge Posner refused to protect an instance of "casual chit-chat" provides the third example. In that case, Judge Posner applied a very particular view of what kind of speech deserves constitutional protection. ${ }^{281}$ Not surprisingly, the kind of speech that Judge Posner viewed as worthy of protection is also the kind of speech that he and his highly-educated colleagues engage in as a matter of daily professional routine. This view of the First Amendment, however, would completely strip constitutional protection from the very kinds of speech-that is, speech about personal matters, individual dreams and aspirations, and interpersonal relationships-that are most important to people outside the political classes. Thus, under these theories of the First Amendment, those who engage in political activity, intellectual public discourse, and other elite activities will receive the many benefits of the Brandenburg paradigm, and those who engage in lesser expressive activities will receive the First Amendment residue. Whatever can be said of these theories, they certainly do not articulate a First Amendment jurisprudence for the masses.

The irony here is that there is no reason to relegate the First Amendment to a narrow range of political topics that are of interest primarily to the political cognoscenti, because the Brandenburg para-

279 Morse v. Frederick, 551 U.S. 393, 408 (2007) (noting that school officials have the authority to discourage drug use and also to restrict student speech celebrating illegal drug use). See Roth v. United States, 354 U.S. 476, 485 (1957) (noting that legislatures have a legitimate interest in regulating obscenity to protect "the social interest in order and morality" (citing Chaplinsky v. New Hampshire, 315 U.S. 568, 571-72 (1942)) (emphasis omitted)).

281 See Swank, 898 F.2d at 1251 (contrasting casual chit-chat with "the advancement of knowledge, the transformation of taste, political change, cultural expression, and the other objectives, values, and consequences of the speech that is protected by the First Amendment"). 
digm provides the government with all the tools necessary to pursue its legitimate regulatory interests in every category of speech. As illustrated in the cases discussed in Part II, supra, the Brandenburg paradigm is easily able to accommodate the government's efforts to protect against harm involving speech in the form of threats, so-called "teaching speech," school speech, and sexually explicit speech. Any government effort to regulate speech in these areas beyond what the Brandenburg paradigm permits inevitably will involve the government in regulating the formulation and communication of ideas rather than the imposition of concrete harms-in other words it will involve precisely the sort of activity in which democratic governments should never be involved. In the end, proponents of the current, multi-level theory of the First Amendment can justify the fracturing of free speech jurisprudence only if they reinterpret the basic nature of democratic governance itself.

\section{CONCLUSION}

Embedded in the Brandenburg paradigm that governs the regulation of political speech under the First Amendment are several assumptions about the nature of democracy and the relationship of democratic government to its citizens. Foremost among these assumptions is the principle that government should not paternalistically seek to substitute its own value judgments for those of its citizens. This leads to the central feature of the Brandenburg regulatory scheme, which is the proposition that speech should be prohibited only when that speech creates such an immediate and grave harm to the public welfare that no other option is available to the government. This Article has been devoted to assessing whether there is any good reason to abandon these assumptions as one moves from the regulation of political speech to the regulation of other types of expression. The answer seems to be a resounding no. People are just as capable of thinking for themselves outside the political arena as they are within it, and nonpolitical harms are just as easy to identify as political harms. As it happens, the Court has, in the Brandenburg paradigm, a handy tool with which to simultaneously recognize the intellectual independence of its citizenry and greatly simplify free speech law, if the Court would only use it. 